\title{
How Polling Place Changes Reduce Turnout: Evidence from Administrative Data in North Carolina*
}

\author{
Jesse Yoder $^{\dagger}$ \\ Department of Political Science \\ Stanford University
}

August 14, 2019

\begin{abstract}
How do changes to voting procedures affect participation in elections? Looking within the state of North Carolina, I estimate the causal effect of Election Day polling place changes on voter participation using detailed voter file information on nearly 4 million individual voters linked with a panel of polling place locations. Implementing a series of difference-in-differences designs, I find that changing a voter's polling place location causes a 1 to 2 percentage point decline in general election turnout likelihood. The majority of the turnout decline can be attributed to the search costs associated with finding one's new polling place location rather than the distance costs of traveling to the polling place on Election Day. This, along with a series of mechanism tests, suggests that providing information to voters is important to help mitigate the voting costs associated with election changes.
\end{abstract}

${ }^{*}$ For helpful comments and discussion, the author thanks Andy Hall, Zhao Li, Hans Lueders, Clayton Nall, Jonathan Rodden, Lauren Sukin, and Dan Thompson, as well as members of the Stanford Working Group on Empirical American Politics Research.

${ }^{\dagger}$ Jesse Yoder is a PhD Candidate in the Department of Political Science at Stanford University (yoderj@stanford.edu; 616 Serra St, Stanford, CA 94305). 
"Voters were confused because of changes to their polling places and a lack of accurate information provided to them by their state officials."

- Sherrilyn Ifill, NAACP Legal Defense and Educational Fund ${ }^{1}$

\section{Introduction}

How do changes to voting procedures affect political participation? A long literature models the voter's turnout decision as a function of the benefits and costs incurred by the voter (Downs 1957; Riker and Ordeshook 1968). When the cost of voting becomes sufficiently high, rational voters choose not to turn out to vote. Even if the act of participating includes benefits apart from influencing the outcome of the election - such as a commitment civic duty, or some other expressive benefit - imposing high costs on voters could still be enough to prevent them from turning out to vote. ${ }^{2}$ Another strand of literature documents large inequalities in political participation in the United States by race, wealth, age, and other factors (Avery and Peffley 2005; Leighley and Nagler 2007, 2013; Verba, Schlozman, and Brady 1995; Wolfinger and Rosenstone 1980). Marrying these two literatures, a plethora of empirical research relates changes in voting costs to voter turnout (Alvarez, Levin, and Sinclair 2012; Berinsky 2005; Burden et al. 2014; Fitzgerald 2005; Fowler 2017; Gronke, Galanes-Rosenbaum, and Miller 2007; Gimpel and Schuknecht 2003; Hajnal, Lajevardi, and Nielson 2017; Haspel and Knotts 2005; Holbein and Hillygus 2016; Oliver 1996).

While the effects voting changes on turnout have generated a lot of public interest in recent American elections, ${ }^{3}$ credibly estimating their causal impact has proven difficult for several reasons. Many voting reforms are state-level policy changes, making it challenging

\footnotetext{
${ }_{1}$ http://www.latimes.com/politics/la-na-pol-election-voting-20161108-story.html

${ }^{2}$ See, for example: Aldrich (1993); Blais (2000); Feddersen (2004); Feddersen and Pesendorfer (1999); Feddersen and Sandroni (2006); Green and Shapiro (1996); Niemi (1976); Riker and Ordeshook (1973); Sanders (1980); Verba, Schlozman, and Brady (1995).

${ }^{3}$ Changes to voting rules have become politically contentious in recent elections. Democrats and Republicans are engaged in "voting wars" over registration rules, early voting opportunities, voter identification laws, and the movement or conslidation of polling places (Hasen 2012). While Republicans argue that these changes help prevent voter fraud, Democrats decry these measures, labeling them as voter suppression tactics that decrease turnout among minority voters, who tend to vote for Democratic candidates.
} 
to estimate causal effects. Therefore, much of the literature on early voting and turnout, for example, reports correlations between between the availability of early voting options and turnout (Gronke, Galanes-Rosenbaum, and Miller 2007; Burden et al. 2014; Giammo and Brox 2010; Wolfinger, Highton, and Mullin 2005), often using individual-level survey data from the Current Population Survey (CPS) or Cooperative Congressional Election Study (CCES), or using aggregate-level turnout in states with and without early voting options. ${ }^{4}$ Another set of papers uses a difference-in-differences approach to estimate the effects of election reforms on turnout, comparing differences in aggregate turnout in states that did and did not adopt various types of election reforms (Burden et al. 2014; Vercellotti and Anderson 2006; De Alth 2009; Alvarez, Bailey, and Katz 2008; Mycoff, Wagner, and Wilson 2009; Dropp 2013). Given the small effective sample size that comes with a state-level difference-in-differences approach, however, these studies are systematically underpowered and cannot estimate effects with the precision required to be policy-relevant (Erikson and Minnite 2009). ${ }^{5}$

To gain some traction on how election reforms affect political participation, in this paper I answer the following question: how do polling place changes affect political participation? Using a series of difference-in-differences along with individual-level administrative voter file data from North Carolina in 2008-2016, I show that Election Day polling place changes cause between a 1 and 2 percentage point decrease in voters' turnout likelihood in general

\footnotetext{
${ }^{4}$ Much of the literature on the introduction of no-excuse absentee voting (e.g., Oliver 1996; Francia and Herrnson 2004; Larocca and Klemanski 2011) and voter ID laws (e.g., Alvarez, Bailey, and Katz 2008; Hajnal, Lajevardi, and Nielson 2017; Mycoff, Wagner, and Wilson 2009; Vercellotti and Anderson 2006) uses the same approach. In addition to the challenges of estimating these types of effects using national surveys, this cross-sectional approach suffers from problems of omitted variable bias arising from the endogeneity of election reforms, so we should be hesitant to interpret the findings from these studies as causal (Grimmer et al. 2018). For example, states adopting more permissive voting laws often have higher levels of turnout prior to reform (Hanmer 2009), which would - to the extent that researchers omit control variables associated both with turnout and the decision to adopt election reforms - bias the estimates reported in these studies in favor of finding demobilizing effects of restrictive voting changes.

${ }^{5}$ Many state-level election reforms are also "bundled," where a collection of election reforms are adopted simultaneously, making it difficult to parse out the effect of any one particular statewide policy change (Leighley and Nagler 2013). For example, North Carolina passed a law in 2013 that instituted many changes - including restricting the number of early voting days for statewide elections, ending pre-registration, and requiring photo identification to vote. (http://www.ncga.state.nc.us/Sessions/2013/Bills/House/ PDF/H589v8. pdf).
} 
elections, on average. By zooming in on this particular reform, which varies within a state, I can rule out concerns that the effects are driven by statewide election reforms, like the implementation of same-day voter registration for early voting in 2007, or a strict photo voter ID law implemented in the 2016 primary election.

I also estimate the effect of polling place changes not just on the turnout decision, but also on which voting method voters use. I find that polling place changes cause a decrease in the likelihood of voting at one's polling place on Election Day, partially offset by an increase in the likelihood of voting using convenience voting methods. ${ }^{6}$ This vote method substitution is concentrated among older voters and homeowners, suggesting that, as voters face changes to Election Day voting, a robust set of convenience voting methods can help to mitigate the decrease in turnout likelihood among these types of voters.

With fine-grained, individual-level administrative data on voter addresses linked to their polling place addresses, I can separate out the "search" versus "distance" costs of polling place changes - that is, the cost of acquiring information about the location of one's new polling place versus the cost of traveling to the polling place on Election Day. ${ }^{7}$ Geocoding each voter's registration address and their corresponding polling place to define a voter's distance from her polling place, I find that search costs drive much of the decrease in turnout, at least in North Carolina. ${ }^{8}$

I also do not find evidence that polling place changes cause larger turnout decreases among Democratic or Black registrants, or that polling place changes decrease precinctlevel Democratic vote share. Some suggestive evidence illustrates one potential reason for this finding - the North Carolina Democratic Party increased its spending in areas with more polling place changes, while the North Carolina Republican Party did not. I also find that polling place changes cause substitution toward convenience voting among older

\footnotetext{
${ }^{6}$ I define convenience voting as voting on a day other than Election Day. In North Carolina, the most common forms of convenience voting are no-excuse absentee by mail and early in-person voting.

${ }^{7}$ See Brady and McNulty (2011) and Amos, Smith, and Claire (2017).

${ }^{8}$ Following the discussion in Brady and McNulty (2011), Haspel and Knotts (2005), and McNulty, Dowling, and Ariotti (2009), I use straight-line distance calculations rather than network distance.
} 
voters and homeowners. These heterogeneous effects, along with the findings that the effects are concentrated in the search cost component and parties strategically mobilize voters in response to polling place changes, suggest that information is critical to explain how polling place changes affect elections. To further test this information mechanism, I leverage the fact that in Wake County, North Carolina the County Board of Elections sent informational mailers to voters when the name (but not location) of their polling place had changed. I find that voters in precincts receiving these extra informational mailers were more likely to vote at their polling place, but not more likely to using convenience methods. Taken together, the evidence suggests that providing voters with additional information about their polling place can reduce voting costs and have a mobilizing effect.

This paper is related to a series of studies on polling place changes (e.g., Haspel and Knotts 2005; Brady and McNulty 2011), ${ }^{9}$ most notably Clinton et al. (N.d.), which examines the effect of polling place changes among North Carolina voters in presidential elections in 2012 and 2016. This presents an exciting and somewhat unique opportunity to consider evidence across two different studies and aggregate them together to learn more about how polling place changes affect voter turnout. Clinton et al. (N.d.) finds that polling place changes reduce Election Day voting, but cause a nearly offsetting substitution toward early voting. Using a similar difference-in-differences design, I come to a slightly different finding from Clinton et al. (N.d.): I find that polling place changes cause a decline in overall turnout of 1 to 2 percentage points, on average. I summarize the key differences below, and provide

\footnotetext{
${ }^{9}$ Brady and McNulty (2011) examines the relationship between turnout and precinct consolidation between the 2002 and 2003 elections in Los Angeles County, finding that polling place changes reduced turnout by at least 1.4 percentage points. Building on the findings in Brady and McNulty (2011), I extend our understanding of how polling place changes impact turnout in three important ways. First, while Brady and McNulty (2011) relates polling place changes and turnout in Los Angeles County, I expand the analysis to include both urban and rural counties in North Carolina. Second, I estimate the effects of polling place changes generally rather than in a context of precinct consolidation. There is often public outcry over the possible political ramifications of precinct consolidation, so there is likely a lot of information being provided to voters in these types of settings (for example, see https://www.nytimes.com/2014/07/ 08/us/08northcarolina.html or http://www.chicagotribune.com/suburbs/post-tribune/news/ctptb-lake-precinct-plan-st-0208-20170207-story.html). Much less is known, however, about the more common general churn from election to election of polling place location changes, which could arise for less nefarious reasons but nonetheless might have important effects on turnout. Third, I estimate how the effects of polling place changes vary along voter characteristics like age, race, and homeownership status.
} 
a full replication of the main Clinton et al. (N.d.) result in A.1 of the Appendix. One key difference between the studies is that, in order to gain more resolution in the timing of the treatment, I collect data on polling place locations in primary and general elections for midterm and presidential election years, i.e., every primary and general election from 2006 through 2016. ${ }^{10}$ This additional data also allows me to estimate the effects of polling place changes on turnout in midterm elections and in primaries, and the longer panel also allows for robust testing of the parallel trends assumption. One drawback of this approach is that polling place lists from North Carolina county boards of elections are availalbe for 35 of North Carolina's 100 counties. While this does not affect the internal validity of the estimates, it might raise concerns over how the results might generalize to the entire state. In the Appendix, I provide some evidence that these 35 counties are slightly more populous than the average county in North Carolina, but otherwise they are quite similar on other observable demographic characteristics.

\section{Voting and Polling Place Changes in North Carolina}

Why do polling places change? To understand when and where polling place changes occur, in Figure 1 I show a series of boxplots with the proportion of voters in each county that experience polling place changes before each election. There are several county-years with no polling place changes, but for many elections at least half of counties have a non-negligible amount of voters affected by polling place changes. The changes occur in both urban and rural counties: in the two most populous North Carolina counties, Mecklenburg and Wake -

\footnotetext{
${ }^{10}$ Second, I use a slightly different method than Clinton et al. (N.d.) to compute an individual's distance from their polling place. I geocode each voter's residential address and compute the straight line distance to their polling place address, while Clinton et al. (N.d.) compute driving travel time from the precinct's geographic centroid to the precint's polling place location. I also show my results are similar when computing the Manhattan distance, which I describe in more detail in the Appendix. I prefer my distance metric because the individual-level measure allows me to identify which voters are closer or farther from their new polling place. An aggregated measure of polling place distance is especially sensitive to measurement error for voters who are not near the centroid of their precinct, which likely explains why the substitution effect toward convenience voting that Clinton et al. (N.d.) find is smaller in magnitude than in my results. For a more detailed discussion considering the two studies, see Section A.1 of the Appendix.
} 


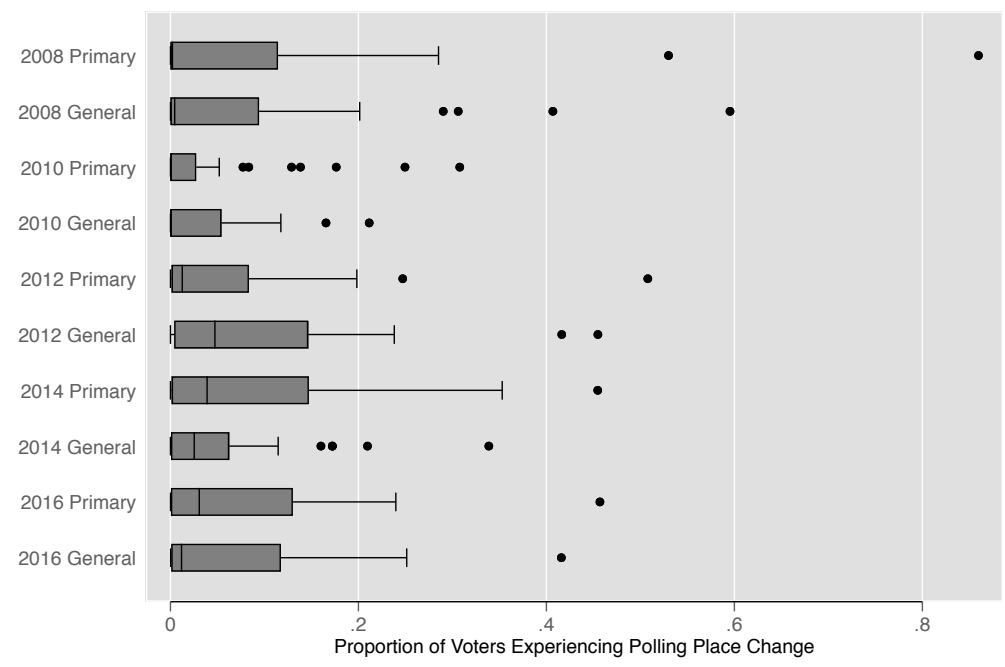

Figure 1 - Proportion of Voters Experiencing Polling Place Changes, by County

This figure shows the a series of boxplots with the proportion of voters in each county experience a polling place change before each election. In every election starting in 2012, more than half of counties had at least one polling place change before the election. In one extreme case, more than $80 \%$ of voters experienced a polling place change before the 2008 primary election in Lee County, North Carolina, which underwent re-precincinting and changed the location of 8 of its 10 polling places.

home to Charlotte and Raleigh, respectively - there are polling places before every primary and general election, with the number of affected voters ranging from 2 to $12 \%$. Polling place changes affect a large proportion of voters in some small counties. For example, more than $80 \%$ of voters experienced a polling place change before the 2008 primary election in Lee County, North Carolina, which underwent re-precincinting and changed the location of 8 of its 10 polling places. Overall, polling place changes occur regularly throughout the period I study, and they happen regularly in both urban and rural counties.

The reasons cited for polling place changes are often mundane and idiosyncratic. Through correspondence with County Boards of Elections in North Carolina, some of the reasons for polling place changes have included parking availability, change of ownership or use of a factility that could no longer accommodate voting, or construction, renovation, or other damage to facilities. Polling place changes due to construction or renovation are sometimes 
temporary. In some cases, staff at County Board of Elections offices have indicated that concerns about safety in schools have prompted polling place changes from schools to other facilities, like churches or community centers. Lastly, staff at some county boards indicated that precinct population growth or decline often prompts polling place changes. Given these cited reasons, along with the fact that polling place changes occur in all types of counties and in each election, it's not likely that polling places are being moved for nefarious reasons, at least for most polling place changes. Later, I show evidence that there is not widespread polling place consolidation in North Carolina generally (Figure 3), or consolidation on a partisan basis (Figure A.5). I do not, however, claim that polling place changes occur at random. Correspondence with County Boards of Elections suggests otherwise. Importantly though, the difference-in-differences design does not require that polling place changes are randomized. I discuss the identification assumptions for my design and provide tests of these assumptions in Section 3.

Several features of North Carolina elections make it a hard test case for whether polling place location changes cause a decrease in political participation. First, in North Carolina citizens can use several methods to vote. Of course, one option is to vote in person at one's polling place on Election Day. ${ }^{11}$ Alternatively, a voter might vote no-excuse absentee by mail or use early in-person absentee voting. For this study, I call these options convenience voting, defined as voting on a day other than Election Day. Convenience voting is fairly common in North Carolina compared to other states, particularly in general elections (Gronke, GalanesRosenbaum, and Miller 2007). ${ }^{12}$ Table 1 shows that convenience voting is actually more common than Election Day voting in North Carolina general elections. About $55 \%$ of general election voters in North Carolina used convenience voting methods in the 2008-2016 general elections. Convenience voting is less common in primary elections - about $24 \%$ of primary

\footnotetext{
${ }^{11} \mathrm{~A}$ voter who decides to vote at their polling place on Election Day has the option to remain in the car outside of their polling place and vote "curbside" due to age or physical disability. In this case, a poll worker brings the ballot to the voter. For the purpose of this study, I code curbside voters as voting in-person on Election Day.

${ }^{12}$ Also, see http://www.electproject.org/2012_early_vote
} 
Table 1 - Descriptive Statistics, Individual Level, North Carolina, 2008-2016.

\begin{tabular}{cccc|ccc}
\hline \hline & \multicolumn{3}{c}{ General } & \multicolumn{3}{c}{ Primary } \\
& Mean & Std. Dev. & $\mathrm{N}$ & Mean & Std. Dev. & $\mathrm{N}$ \\
& $(1)$ & $(2)$ & $(3)$ & $(4)$ & $(5)$ & $(6)$ \\
\hline Voted & 0.546 & 0.498 & $13,315,719$ & 0.250 & 0.433 & $12,063,514$ \\
Voted at Polling Place & 0.254 & 0.435 & $13,315,719$ & 0.192 & 0.394 & $12,063,514$ \\
Voted Convenience & 0.292 & 0.455 & $13,315,719$ & 0.058 & 0.234 & $12,063,514$ \\
Polling Place Change & 0.059 & 0.236 & $13,315,719$ & 0.066 & 0.248 & $12,063,514$ \\
\hline \hline
\end{tabular}

Note: The first three columns present individual level descriptive statistics for general elections, while the last three columns are for primary elections. The polling place change variable is calculated as whether an individual voter has had her polling place location changed since the last general (or primary) election two years prior. Voted is calculated as the sum of Voted at Polling Place and Voted Convenience.

election voters used convenience voting methods in the 2008-2016 primary elections. Given that convenience voting is so common in North Carolina, we might expect the effects of polling place changes to be smaller than in other settings. A smaller proportion of the electorate uses Election Day polling place voting in the first place, and voters facing polling place changes have a whole host of voting methods available to substitute toward in order to help alleviate the voting costs associated with polling place changes.

Second, the average voter in North Carolina that experiences a polling place change is no closer or farther than from their original polling place. In other words, this is a setting with very little precinct or polling place consolidation. Rather, the vast majority of these polling place changes are simply polling place location changes without a change or consolidation of precincts. The left panel in Figure 2 shows the distribution of Euclidean distances from voters' registration addresses to their assigned Election Day polling place. ${ }^{13}$ The vertical line shows that the mean distance from polling place is about 1.5 miles. The right panel in Figure 2 shows the distribution of change in polling place distance for those voters who experienced polling place changes between any two given elections. The mean of this distribution are both

\footnotetext{
${ }^{13}$ Here I use distance from an individual's registered address to their polling place, but this might be a noisy measure of distance if voters consider distance from locations other than their address, like their workplace for example (Stein and Vonnahme 2008). This would attenuate estimates of the effect of changes in polling place distance on turnout.
} 


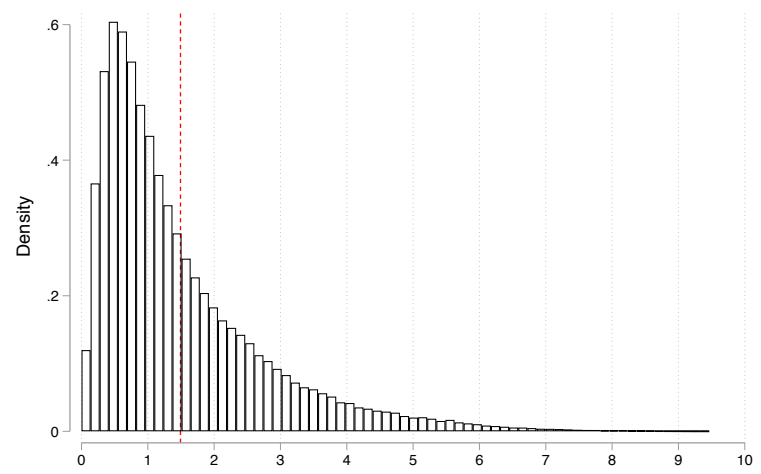

(a) Distance from Polling Place (Miles)

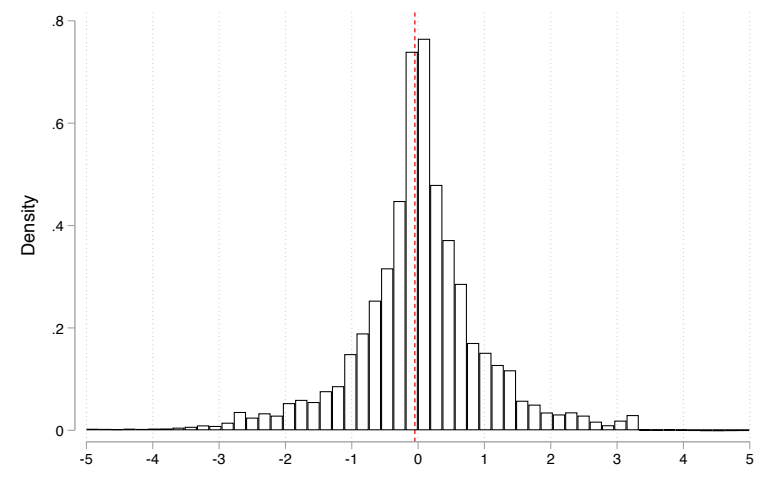

(b) Change in Distance from Polling Place (Miles)

Figure 2 - Polling Place Distance - The figure on the left shows the density of polling place distances in miles, with the vertical dashed line representing the mean polling place distance. The right figure shows the change in polling place distance among those who experienced a polling place change, wwith the vertical dashed line again representing the mean.

very close to zero, suggesting that there is not widespread precinct consolidation in North Carolina during this period. In Figure A.5 in the Appendix, I show the change in distance from one's polling place among different groups of voters and by partisan composition of County Boards of Elections, which are responsible for determining polling place locations. I do not find systematic differences in changes in polling place distance along these dimensions.

Third, North Carolina law requires that County Boards of Elections take several steps to notify voters of polling place changes. More than $6 \%$ of voters had their polling place changed between any two given elections, and about $19 \%$ of voters experience a polling place change at some point from 2008-2016. ${ }^{14}$ For each of these voters experiencing a polling place change, North Carolina law requires that counties take several steps to notify affected voters. The law requires that,

"Notice [of precinct or polling place changes] shall be given by advertisement in a newspaper having general circulation in the county. Notice may additionally be

\footnotetext{
${ }^{14}$ To avoid bias from selection into treatment, I omit registrants that change their address from the previous election period. Because movers make the decision about whether to re-register at their new address, I only want to keep those whose address has not changed but who have their polling place location changed between elections.
} 
made on a radio or television station or both. No later than 30 days prior to the ... election, the county board of elections shall mail a notice ... to each registered voter who as a result of the change will be assigned to a different voting place." 15

While one might expect polling place changes to decrease turnout likelihood by increasing the costs associated with voting, these notification requirements suggest a potentially offsetting effect on turnout through mobilization. If citizens are sent a mailer describing how to vote at their new polling place on Election Day and are informed of polling place changes through a variety of media outlets, these notifications could mitigate the information costs associated with finding a new polling place. For these reasons, North Carolina represents a case where one might expect the effects of polling place changes on turnout to be less extreme than in other settings - where there are fewer alternatives to Election Day voting or where notification requirements about polling place changes are less stringent.

I also limit the analysis to North Carolina because it has useful information about voters and polling place locations that is not available in other states. The North Carolina voter file has individual-level voter turnout, along with vote method, for every election dating back to the 2008 primary. It also contains information on voter names, registration address, party registration, age, and race. But most importantly, unlike other states North Carolina keeps a series of voter file snapshots. One well-known issue with using voter files in these types of analyses is that their composition changes over time. If individuals who have their polling places changed drop out of the voter file at a different rate than those who do not, then failing to include these voters would induce a post-treatment bias in the estimates. To avoid this, I use the North Caroilna voter file snapshots to include all voters who appear in earlier versions of the voter file but were eventually removed, and I code them as not having voted. Observing the voter file at various points in time over the course of study period also helps to minimize issues related to re-precincinting over time. Given that I can observe a voter's assigned precinct during multiple periods, I can mitigate the error in determining a voter's

\footnotetext{
${ }^{15}$ See http://www.ncga.state.nc.us/gascripts/statutes/statutelookup.pl?statute=163-128
} 
assigned polling place that would be generated by changing precinct boundaries. I provide a detailed description of how I assembled the dataset in Section A.4 of the Appendix.

\section{Polling Place Changes Decrease General Election Turnout}

I first estimate the effects of polling place changes on voter turnout using a difference-indifferences design. Specifically, I estimate equations of the form

$$
\text { Voted }_{i t}=\beta \text { Polling Place Change } i t+\gamma_{i}+\delta_{t}+\epsilon_{i t},
$$

where $\operatorname{Voted}_{i t}$ takes on a value of 1 if individual $i$ voted in election $t$, and 0 otherwise. In some specifications, this is defined as voting in person on Election Day or voting using convenience methods. The variable Polling Place Change ${ }_{i t}$ takes on a value of 1 if individual $i$ had their Election Day polling place changed between the election in time $t$ and the election in time $t-1$. The $\gamma_{i}$ and $\delta_{t}$ terms represent individual and year fixed effects, respectively. In this difference-in-differences framework, I compare within-voter changes in turnout over time across the polling place change treatment. For the estimate to be causal, it is not required that polling place changes occur at random. In Section 2 I discuss some of the reasons why polling place changes occur, and they certainly are not randomized. Rather, to identify the effect, the parallel trends assumption must be satisfied - that is, it must be that the turnout trends for voters that did not experience polling place changes provide a valid counterfactual trend for voters that did experience a polling place change. I use three strategies to test the plausibility of the parallel trends assumption in Section A.3 of the Appendix. I include a lead of the polling place variable to check for evidence of pretrending, I vary the set of fixed effects to construct alternative counterfactual trends, and I model the dynamic effect of polling place changes (Angrist and Pischke 2008; Autor 2003). All of the results, which I discuss in more detail in the Appendix, are reassuring that parallel trends is a valid assumption. 
Table 2 - Effects of Polling Place Changes on General Election Turnout, Individual Level, 2008-2016.

\begin{tabular}{lccc}
\hline \hline & $(1)$ & $(2)$ & $(3)$ \\
\hline & \multicolumn{3}{c}{ A. Voted } \\
\cline { 2 - 4 } Polling Place Moved & $\begin{array}{c}-0.011 \\
(0.002)\end{array}$ & $\begin{array}{c}-0.019 \\
(0.009)\end{array}$ & $\begin{array}{c}-0.008 \\
(0.007)\end{array}$ \\
\hline & \multicolumn{2}{c}{ B. Voted at Polling Place } \\
\cline { 2 - 4 } Polling Place Moved & -0.010 & -0.030 & -0.016 \\
& $(0.003)$ & $(0.019)$ & $(0.012)$ \\
& \multicolumn{2}{c}{ C. Voted Convenience } \\
\cline { 2 - 4 } Polling Place Moved & -0.001 & 0.011 & 0.008 \\
& $(0.003)$ & $(0.015)$ & $(0.009)$ \\
\hline Sample & Full & Primary & General \\
N & $13,315,719$ & $2,383,803$ & $1,595,522$ \\
V Voters & $3,869,787$ & $1,257,927$ & $1,100,761$ \\
Election FEs & Yes & Yes & Yes \\
Voter FEs & Yes & Yes & Yes \\
\hline \hline
\end{tabular}

Robust standard errors clustered by precinct in parentheses. The outcome in Panel A is voting in the general election, the outcome in Panel B is voting at the polling place in the general election, and the outcome in Panel $\mathrm{C}$ voting using convenience methods in the general election. The full sample includes all voters, the primary sample subsets to those who voted in the primary election in the present year, and the general sample subsets to those who voted in the prior general election but not in the primary in the present year. Polling Place Moved is a binary variable indicating that one's polling place location changed from the previous general election (or from the primary election for Panel B).

Table 2 presents the main difference-in-differences estimates, which includes individual and election fixed effects. In Panel A, the outcome is whether or not the individual voted in the general election, and the polling place moved variable is whether or not the voter had their polling place moved since the previous general election. The estimate of interest, the coefficient on the polling place moved variable, suggests that having one's polling place moved decreases a voter's general election turnout likelihood by 1.1 percentage points, on average (column 1). 
While the first column estimates the overall effect of polling place changes on a voter's likelihood of voting in the general election, the sample in that column includes registrants who did not vote at their Election Day polling place prior to receiving the polling place change treatment. To the extent that polling place changes only impose costs on voters who already have knowledge of the original polling place location, many of the observations coded as having had a polling place change do not actually incur these additional costs. One might be tempted to consider an alternative treatment variable, where polling place change is coded as a 1 if a voter's polling place has changed since the last time they voted. However, that would induce post-treatment bias because the polling place change variable would be a function of the voter's turnout behavior after the initial polling place change occurs, and it would lead me to drastically overestimate the magnitude of any demobilizing effect. To zoom in on voters likely affected by polling place changes, but still avoid concerns about posttreatment bias, in column 2 I subset to individuals who voted at their polling place in the primary election and then went on to have their polling place changed between the primary and general election. I find that polling place changes decrease turnout by 1.9 percentage points among this subset of voters. Of course, the estimate in column 2 is for a specific group of voters - those who vote at their polling place during the primary - who perhaps are types that are more likely to acquire information about polling place changes than the the general voting population. In column 3 I subset to voters who voted at their polling place in the previous general election, again with the idea that voters are most likely to incur the search costs associated with polling place changes if they have previously voted at the polling polling place. The outcome in Panel B is voting at one's polling place on Election Day, while the outcome in Panel $\mathrm{C}$ is voting using convenience methods. As expected, the decrease in turnout associated with polling place changes is concentrated in polling place voting, not in convenience voting. ${ }^{16}$ I report results for primary rather than general election

\footnotetext{
${ }^{16}$ In Table A.8 in the Appendix, I further decompose convenience voting into absentee by mail and early in person voting. The results show that polling place changes do not cause a meaningful decline in either voting absentee by mail or voting early in person.
} 
turnout in Table A.9 of the Appendix. Interestingly, the magnitude of the effects is much smaller in primary election settings, which suggests that the voting costs imposed by polling place changes are more important for general election voters.

One desirable feature of this design is that it controls for common-shocks affecting turnout. It controls for changes to voting procedures that affect all voters in the state, like the implementation of same day voting registration for early voters in 2007. However, if these voting reforms affect turnout differently for different types of voters, and these differences also correlate with polling place changes, that could introduce bias in the estimate. For example, if students are more likely to use same day voting registration and are more likely to have their polling place changed, this would lead me to underestimate the magnitude of the effect of polling place changes. To control for these types of potential confounders, in Table A.5 in the Appendix I include different sets of time fixed effects in order to vary the control units used to construct counterfactual turnout trends. For example, I use countyby-age-by-election fixed effects so that each treated unit's counterfactual turnout trend is computed using only individuals who are the same age and live in the same county but did not experience a polling place change. The effects are similar across a variety of specifications in Table A.5, suggesting that the differential impact of other statewide voting reforms are not driving the results.

So far, I have estimated the overall effect of a polling place change on turnout. However, polling place changes could have two effects, which I can separate empirically. In Section A.2 in the Appendix, I present a simple model to illustrate these different possible effects. The first is the search effect from the costs of finding a new polling place after it has changed, while the second is a transportation effect from the change in distance to the polling place after it has changed (Brady and McNulty 2011). To separate these effects, I use GIS software to geocode each voter's address from the voter file along with their corresponding polling place, and I calculate the voter's distance from their Election Day polling place in every election. For each voter, therefore, I can observe not only whether or not their polling place 
was changed, but also how far their old and new polling places are from their registered address. ${ }^{17}$ I evaluate distance from polling place as the Euclidean (straight-line) distance from a voter's address in the voter file to their assigned polling place. ${ }^{18}$ Then, I define a change in distance variable (shown in the right panel of Figure 2), and construct deciles of these changes in distance. Next, I estimate the effect of polling place changes on turnout (the equivalent of the model from Column 1 in Panel A of Table 2) for each distance change decile. For example, the treatment group for the first decile contains voters experiencing polling place changes whose new polling place is much closer to them than their previous polling place, while the treatment group for the tenth decile contains voters whose new polling place is much farther from them than their previous polling place. If voters are sensitive to transportation costs, the demobilizing effect of polling place changes should be larger for those in higher deciles. Figure 3, however, shows no clear relationship between the effect of polling place changes across changes in distance. ${ }^{19}$ This is at least suggestive evidence that most of the decline in turnout caused by polling place changes can be attributed to the search costs associated with polling place changes rather than transportation costs.

Next, I estimate whether these general election polling place change effects differ across subgroups. Critics of changes to voting rules argue that these changes disproportionately burden minority communities, who also tend to support Democratic candidates. Are these groups more sensitive to polling place changes? In Table A.10 in the Appendix I interact polling place changes with whether a voter is registered as a Democrat, whether a voter's race is listed as Black in the voter file, and a zip code-level measure of percent urban as

\footnotetext{
${ }^{17}$ One limitation of this approach is that the distance calculation is from a voter's registered address. Voters, of course, could evaluate distance costs from other locations, such as place of employment, when considering distance from polling place in their turnout decision.

${ }^{18}$ One might argue that Euclidean distance does not accurately capture the transportation costs from a voter's residence to their polling place, especially in urban areas. As a robustness check, in Section A.2 in the Appendix I do all distance analyses using a Manhattan distance metric. The results are substantively similar, which is unsurprising given that previous research in this area finds that these types of results are often not sensitive to choice of distance metric (Haspel and Knotts 2005; McNulty, Dowling, and Ariotti 2009).

${ }^{19}$ In Figure A.2 in the Appendix, I show that the results are substantively similar if I use Manhattan distance rather than Euclidean distance.
} 


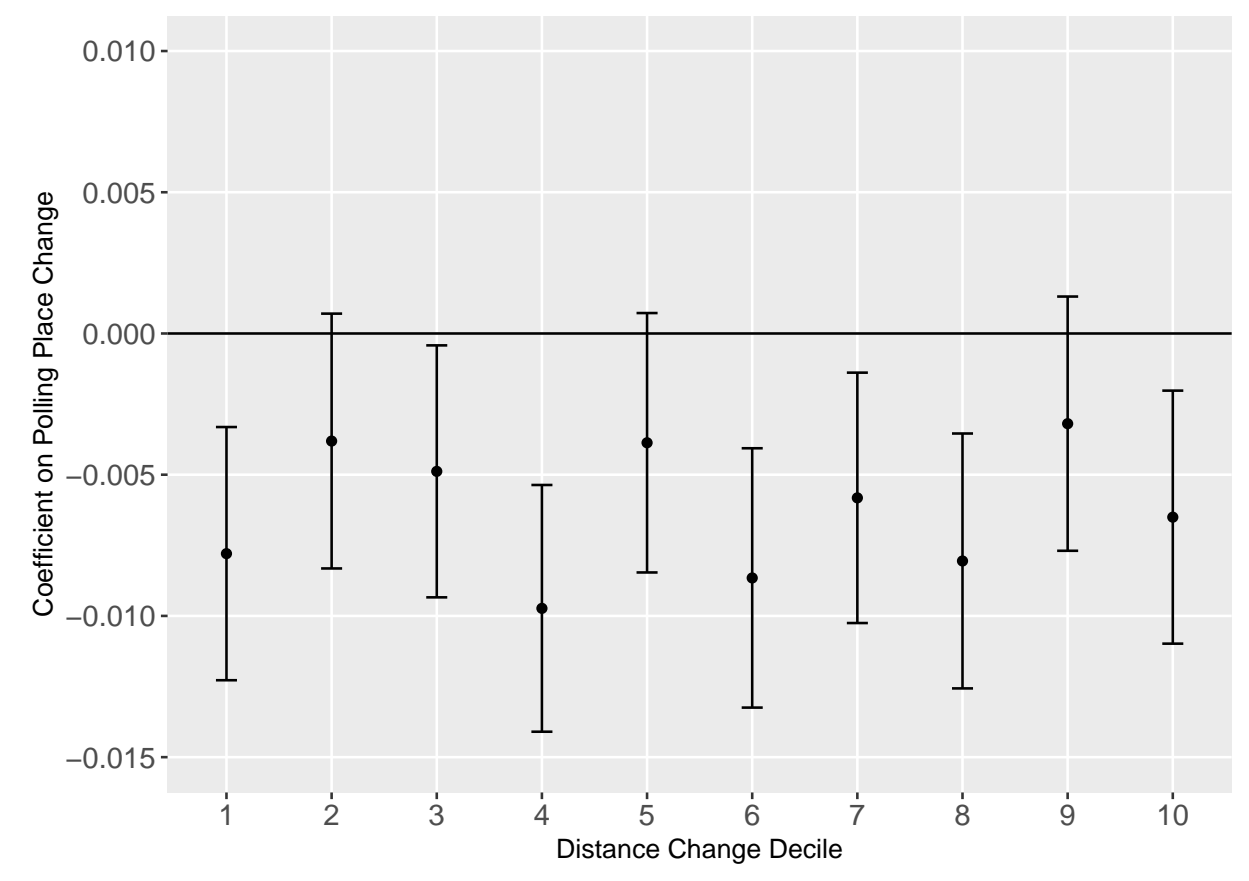

Figure 3 - Effect of Polling Place Change Across Distance Change

This figure shows coefficient estimates of the effect of polling place changes on turnout across changes in polling place distance. The $\mathrm{x}$-axis is the decile of the change in distance from one's polling place. Each point represents a coefficient estimate from the specification in Column 1, Panel A of Table 2, but using only those within distance change decile as the treatment group. There appears to be no systematic relationship between change in polling place distance and the effect of polling place changes, suggesting that most of the effect can be attributed to search costs rather than transportations costs. 
defined by the US Census. Overall, there is not strong evidence to suggest that the effects of polling place changes vary importantly along these dimensions. The effect on voting at one's polling place is about 0.7 percentage points larger (more negative) for Democrats than for non-Democrats, but Democrats facing polling place changes are slightly more likely to use convenience voting methods.

\subsection{Effect Size and Possible Sources of Attenuation Bias}

So far, I have shown that polling place changes decrease general election turnout, and in Section 2 I discussed some of the features of North Carolina elections that make it a setting where we might expect to see smaller effects of these changes than in other settings. In this section, I elaborate on some of the features of the data that might also lead to underestimating the magnitude of these effects. First, as outlined before, the specification in column 1 includes registrants who had never voted at their Election Day polling place prior to experiencing the polling place change. To zoom in on voters who had voted at their polling place before it was moved, I subset to subset to primary voters in Panel B of Table 2. I see that the demobilizing effect is much greater among these voters.

Second, the voter file snapshots used to generate assigned precincts for each election period are measured infrequently. ${ }^{20}$ To the extent that re-precincting along with occasional differences between the voter file snapshot date and the election date generate precinct mismeasurement, it is possible that some voters that experienced a polling place change due to re-precincting will be coded as not being "treated" with the polling place change, or vice versa. Because there are only a few elections for which I do not have a voter file snapshot from the exact election date, this source of bias is unlikely to be a major concern. Third, in order to avoid selection into treatment induced by voters moving and re-registering, I only include registrants whose address remains the same from the previous election period. Therefore, the effects are local to stayers rather than movers, a subset of people that we might have

\footnotetext{
${ }^{20}$ In Section A.4 of the Appendix I provide a detailed description of voter file snapshot dates and generating each voter's precinct for a given election.
} 
reason to believe are less sensitive to voting costs associated with polling place changes. For example, they could be more familiar with their neighborhood, have lower transportation costs, or be more likely to acquire information about polling place changes. Lastly, these estimates report the general equilibrium effect of polling place changes, so it includes the mobilizing effect of counties, parties, and other groups strategically responding to polling place changes by informing and mobilizing voters. ${ }^{21}$ Given that I still find negative effects of polling place changes on turnout, we can be confident that there is at least a negative partial equilibrium effect of polling place changes on turnout.

\subsection{Polling Place Changes Do Not Decrease Democratic Vote Share}

Related to heterogeneous effects of polling place changes on turnout, critics of changes to voting rules argue that they will disadvantage Democrats in elections. To test this, in Table 3 I use difference-in-differences to estimate the effects of polling place changes on the precinctlevel Democratic two-party vote share in US President, US Senate, and US House elections. The first two columns estimate the effects for Presidential races, so it includes the 2008, 2012 and 2016 elections. The second two columns estimate the effects for the US Senate, which includes each general election from 2008-2016 except for 2012. The last two columns estimate the effects for the US House, so it includes all general elections from 2008-2016. Each specification includes precinct and election fixed effects, and even-numbered columns weight the estimates by the number of registrants in each precinct. Overall, I find precisely estimated null effects of polling place changes on Democratic vote shares in elections for the US President and US Senate. The point estimates range from about -0.15 to 0.3 percentage points, and we can generally rule out effects greater than about 1 percentage point. The last two columns suggest that, if anything, polling place changes cause a small increase in

${ }^{21}$ A long history of political science literature documents how political parties seek to mobilize voters (e.g., Huckfeldt and Sprague 1992; Morton 1991; Rosenstone and Hansen 1993; Shachar and Nalebuff 1999; Uhlaner 1989). 
US House Democratic vote share, which is the opposite of what the conventional wisdom around the effects of polling place changes on elections would predict.

Table 3 - Effects of Polling Place Changes on Democratic Vote Share, Precinct Level, 2008-2016.

\begin{tabular}{lcccccc}
\hline \hline Democratic Vote Share & \multicolumn{2}{c}{ President } & \multicolumn{2}{c}{ US Senate } & \multicolumn{2}{c}{ US House } \\
& $(1)$ & $(2)$ & $(3)$ & $(4)$ & $(5)$ & $(6)$ \\
\hline PP Change & 0.020 & -0.154 & 0.312 & 0.269 & 0.990 & 1.391 \\
& $(0.433)$ & $(0.450)$ & $(0.433)$ & $(0.476)$ & $(0.561)$ & $(0.647)$ \\
\hline $\mathrm{N}$ & 3,214 & 3,214 & 4,270 & 4,270 & 5,347 & 5,347 \\
$\#$ Precincts & 1,110 & 1,110 & 1,109 & 1,109 & 1,110 & 1,110 \\
Election FEs & Yes & Yes & Yes & Yes & Yes & Yes \\
Precinct FEs & Yes & Yes & Yes & Yes & Yes & Yes \\
Precinct Weights & No & Yes & No & Yes & No & Yes \\
\hline \hline
\end{tabular}

Note: Robust standard errors clustered by precinct in parentheses. The outcome is twoparty Democratic vote share for President (Columns 1 and 2), US Senate (Columns 3 and 4 ), and US House (Columns 5 and 6). PP Change is a binary indicator for whether the precinct's general election polling place was changed from the previous general election. Even-numbered columns include weights for the number of voters in the precinct-year.

\section{Understanding the Information Mechanism}

The results presented so far suggest that information is the primary mechanism by which polling place changes reduce turnout. For example, I find that the majority of the decline in turnout induced by polling place changes can be attributed to the search costs associated with finding a new polling place rather than travel costs. In this section, I present a series of tests to help understand more about how providing information to voters about polling place changes affects their likelihood of political participation.

\subsection{Democrats Increase Spending in Areas with More Polling Place Changes}

Contrary to some of the conventional wisdom around heterogeneous effects of election changes

- that these changes cause a disproportionate decline in turnout among Democratic voters - I 
reported earlier that polling place changes do not cause a differential turnout declines among Democratic and Black registrants, and they do not cause a decrease in Democratic vote share. There are two potential explanations, however, for these findings. First, it could be that the average effect for each of these subgroups is indeed similar to their reference group. Second, it could be that these groups would have incurred larger voting costs from polling place changes, but parties and other groups strategically mobilize and provide information about polling place changes to those perceived as being disproportionately burdened by these types of election changes. To test this, in Table 4 I estimate the effects of polling place changes on spending by the North Carolina Democratic and Republican parties. The outcome variable is the logged value of the total disbursements that parties report to the Federal Election Commission (FEC), plus one. The data on disbursements is reported at the zip code-level, so the unit of analysis is the zip code-election year. Because I can observe a voter's registered zip code in the voter file, I construct the treatment variable as the proportion of voters in the zip code that experience a polling place change before the general election in a given year, and this variable ranges from 0 (meaning no voters in the zip code had their polling place changed) to 1 (meaning all voters in the zip code had their polling place changed). I include zip code fixed effects in all specifications in order to control for the time-invariant characteristics of a zip code that influence spending - like where the party is headquartered, for example. I also include election fixed effects to control for common shocks to all zip codes across years - for example, parties spend more in presidential election years than in nonpresidential election years. The first two columns report the effects of polling place changes on disbursements for the North Carolina Democratic Party, while the second two columns report the effects for the North Carolina Republican Party. Odd-numbered columns include all disbursements, while even-numbered columns subset only to campaign-related spending. Overall, I find that the North Carolina Democratic Party increases its spending in zip codes 
where more voters experienced polling place changes. ${ }^{22}$ Meanwhile, I do not find evidence that the North Carolina Republican Party increases its spending in zip codes with more polling place changes. While the estimates are somewhat noisy, it does provide suggestive evidence for the explanation that parties respond strategically to election changes, and this could be at least part of the explanation for why we do not observe disproportionate decreases in turnout among Democratic or Black voters and why we do not find effects of polling place changes on Democratic vote share. The observed non-effects on vote share, in equilibrium, could be capturing the increased efforts of the Democratic party to inform and mobilize voters affected by polling place changes.

\subsection{Older Voters and Homeowners are More Likely to Substitute Toward Convenience Voting}

I can also exploit other individual-level heterogeneity in treatment effects to provide another test of the information mechanism in explaining turnout. North Carolina law requires that polling place change notices be circulated by newspaper, a resolution posted at the county board of elections office, and through mailers sent to individuals affected by polling place changes. Counties also sometimes provide notice through radio or television. Given that these forms of communication about polling place changes are often through traditional media and information sources, we might expect that older voters and homeowners would be less sensitive to the voting costs imposed by polling place changes.

In Table 5 I explore how the effects of polling place changes vary by homeownership and age. While it is not a perfect measure, here I think of homeownership as an individual-level proxy for socioeconomic status. The information on homeownership comes from CoreLogic, a private data vendor that collects public tax and deed records from each county in the United

\footnotetext{
${ }^{22}$ There is almost certainly a good deal of measurement error in the reported zip code for the disbursements and the zip code where the campaign funds are actually spent. For example, parties will often report large expenditures for printing, postage, or robo-calls to an out-of-state zip code. The extent to which there is measurement error in the FEC-reported zip code and the zip code that the expenditures eventually targets, however, should attenuate the reported estimates.
} 
Table 4 - Effects of Polling Place Changes on State Party Committee Spending, Zip Code Level, 2008-2016.

\begin{tabular}{lcc|cc}
\hline \hline & \multicolumn{2}{c}{ Democratic Party } & \multicolumn{2}{c}{ Republican Party } \\
Log(Disbursements + 1) & All & $\begin{array}{c}\text { Campaign } \\
\text { Expenses }\end{array}$ & All & Campaign \\
& & & Expenses \\
& $(1)$ & $(2)$ & $(3)$ & $(4)$ \\
\hline \% PP Change & 2.984 & 2.926 & 0.114 & -0.245 \\
& $(0.934)$ & $(0.890)$ & $(0.881)$ & $(0.819)$ \\
\hline $\mathrm{N}$ & 1,994 & 1,994 & 1,994 & 1,994 \\
\# Zip Codes & 424 & 424 & 424 & 424 \\
Election FEs & Yes & Yes & Yes & Yes \\
Zip Code FEs & Yes & Yes & Yes & Yes \\
\hline \hline
\end{tabular}

Note: Robust standard errors in parentheses. The outcome in each column is the logged value of the total number of disbursements in the zip-code plus one. Columns 1 and 2 use disbursements from the North Carolina Democratic Party, while Columns 3 and 4 use disbursements from the North Carolina Republican Party. Columns 1 and 3 include all disbursements reported to the Federal Election Commission, while Columns 2 and 4 include only campaign-related disbursements. \% PP Change is the proportion of voters in each zip code whose Election Day polling place location was changed from the previous general election. Estimates are weighted by the number of voters in the zip code.

States. The data includes information on property type, names of property owners, full address, and purchase date and purchase price of properties, along with other information. I merge these property records to the North Carolina voter file to identify which registered voters are homeowners. I describe the details of the linking procedure in the Appendix.

I find that the decline in turnout from polling place changes is 0.8 percentage points smaller for homeowners than for non-homeowners. Perhaps more interestingly, homeowners are less likely than non-homeowners to vote at their polling place when their polling place is changed (Column 3), but they are much more likely to substitute toward convenience voting than non-homeowners (Column 5). That is, the vote method switching behavior is concentrated among homeowners. Again, mapping the empirical results back to the theory, it appears that high SES individuals tend to be potential switchers, while lower SES individ- 
Table 5 - Effects of Polling Place Changes on General Election Turnout by Homeownership and Age, Individual Level, 2008-2016.

\begin{tabular}{|c|c|c|c|c|c|c|}
\hline & \multicolumn{2}{|c|}{ Voted } & \multicolumn{2}{|c|}{ Voted at Polling Place } & \multicolumn{2}{|c|}{ Voted Convenience } \\
\hline & (1) & $(2)$ & (3) & (4) & (5) & (6) \\
\hline \multirow[t]{2}{*}{ PP Change } & -0.014 & -0.018 & -0.006 & 0.002 & -0.009 & -0.020 \\
\hline & $(0.002)$ & $(0.006)$ & $(0.003)$ & $(0.008)$ & $(0.003)$ & $(0.006)$ \\
\hline \multirow[t]{2}{*}{ Homeowner } & 0.032 & & 0.016 & & 0.016 & \\
\hline & $(0.002)$ & & $(0.002)$ & & $(0.002)$ & \\
\hline \multirow[t]{2}{*}{ PP Change ${ }^{*}$ Homeowner } & 0.008 & & -0.013 & & 0.022 & \\
\hline & $(0.003)$ & & $(0.005)$ & & $(0.006)$ & \\
\hline \multirow[t]{2}{*}{ Age $31-45$} & & 0.001 & & 0.015 & & -0.014 \\
\hline & & $(0.001)$ & & $(0.001)$ & & $(0.001)$ \\
\hline \multirow[t]{2}{*}{ PP Change $*$ Age $31-45$} & & 0.010 & & -0.004 & & 0.014 \\
\hline & & $(0.006)$ & & $(0.007)$ & & $(0.005)$ \\
\hline \multirow[t]{2}{*}{ Age 46-60 } & & 0.024 & & 0.019 & & 0.005 \\
\hline & & $(0.002)$ & & $(0.002)$ & & $(0.002)$ \\
\hline \multirow[t]{2}{*}{ PP Change $*$ Age $46-60$} & & 0.007 & & -0.017 & & 0.024 \\
\hline & & $(0.007)$ & & $(0.009)$ & & $(0.007)$ \\
\hline \multirow[t]{2}{*}{ Age $61-75$} & & 0.055 & & 0.015 & & 0.040 \\
\hline & & $(0.002)$ & & $(0.002)$ & & $(0.002)$ \\
\hline \multirow[t]{2}{*}{ PP Change $*$ Age $61-75$} & & 0.003 & & -0.025 & & 0.028 \\
\hline & & $(0.008)$ & & $(0.010)$ & & $(0.007)$ \\
\hline \multirow[t]{2}{*}{ Age $76+$} & & 0.026 & & 0.008 & & 0.018 \\
\hline & & $(0.003)$ & & $(0.002)$ & & $(0.003)$ \\
\hline \multirow[t]{2}{*}{ PP Change ${ }^{*}$ Age $76+$} & & 0.012 & & -0.021 & & 0.033 \\
\hline & & $(0.009)$ & & $(0.009)$ & & $(0.007)$ \\
\hline $\mathrm{N}$ & $13,315,719$ & $13,315,719$ & $13,315,719$ & $13,315,719$ & $13,315,719$ & $13,315,719$ \\
\hline \# Voters & $3,869,787$ & $3,869,787$ & $3,869,787$ & $3,869,787$ & $3,869,787$ & $3,869,787$ \\
\hline Election FEs & Yes & Yes & Yes & Yes & Yes & Yes \\
\hline Voter FEs & Yes & Yes & Yes & Yes & Yes & Yes \\
\hline
\end{tabular}

Note: Robust standard errors clustered by precinct in parentheses. The omitted category in the age regressions is Age 18-30. Homeowner is an indicator for whether the individual is listed as a homeowner at any time in the period between the general election and the prior general election. The outcome in Columns 1 and 2 is a whether an individual voted in the general election, the outcome in Columns 3 and 4 is whether an individual voted at her polling place in the general election, and the outcome in Columns 5 and 6 is whether an individual voted using convenience methods in the general election. 
uals tend to be potential abstainers. In terms of bias specific to the homeowner indicator, any errors in merging the voter file to the property records could generate false positives or negatives. However, this merge error would attenuate the effects in the homeownership interaction, so finding a difference nonetheless provides compelling evidence that there are indeed differences in how homeowners and non-homeowners respond to polling place changes. ${ }^{23}$

There are also important differences in the effects with respect to age. I construct five age bins and include a set of age interactions with age 18-30 as the omitted category. Looking at the interaction terms in Column 2 of Table 5, all of which are positive, it appears that older voters are slightly less sensitive to polling place changes than younger voters - although the interaction effects are imprecisely estimated. Also, older voters, much like homeowners, are much more likely to exhibit this switching behavior in response to polling place changes than younger voters. Examining the interaction terms in Columns 4 and 6, older voters are less likely than younger voters to vote at their polling place in response to a polling place change, but they are much more likely to vote using convenience methods. The results for vote method helps to clarify a potential mechanism, which is that older voters are able to acquire information about their polling place location, and they are perhaps even mobilized by this information. This heterogeneity in effects by age could be driven by differences in the ease and method by which older and younger voters seek out or can be reached with information about voting changes.

\subsection{Providing Information to Voters Has a Mobilizing Effect}

An ideal experiment designed to test the information mechanism directly would be to randomize whether or not a voter receives information when their polling place is changed, and

\footnotetext{
${ }^{23} \mathrm{I}$ also estimate how the difference in effects of polling place changes between homeowners and nonhomeowners varies by wealth. In Figure A.4, I create home value deciles and estimate the interaction term from Column 1 of Table 5 for each home value decile. The dotted line in Figure A.4 represents the coefficient estimate on the interaction term in Column 1 of Table 5, which can be interpreted as the difference in effects of of polling place changes for homeowners versus non-homeowners. Each point, then, represents this coefficient estimate for each home value decile. Given that there is no clear relationship between the coefficients across home value deciles, we can conclude that homeowners seem to be less sensitive to polling place changes than non-homeowners, regardless of wealth.
} 
examine whether the effect of the polling place change on turnout varies with information provision. Unfortunately (from the researcher's perspective), all voters in North Carolina are provided with informational mailers notifying them of polling place location changes, per North Carolina law. In the absence of this type of randomization, I test for the effect of polling place-related information provision on turnout by exploiting a specific policy in Wake county that generates a natural experiment. In Wake County, voters are notified by the County Board of Elections when the name of their assigned polling place changes, regardless of whether or not the physical location of the polling place changed. The County Board sends new voter registration cards to any voters experiencing polling place changes, but they also send new voter registration cards with a special insert indicating when there has been a polling place name change even if there is no change in polling place location. A copy of the insert is shown in Figure A.6 in the Appendix. If it is the case that providing information to voters about their polling place location increases turnout likelihood, then we should observe higher turnout on average among voters that receive this additional informational mailer even when their polling place location has not changed. To test this, in Table 6 I subset to voters in Wake County that did not have their polling place location changed from the previous election, meaning I hold the actual polling place fixed for all voters in the sample. The treatment, then, is whether or not the polling place name had changed from the previous election period, which generates the informational mailer. I estimate the effect of the polling place name change on turnout and find that voters receiving the polling place mailer are more likely to vote at their polling place, but not more likely to use convenience voting methods. This is additional suggestive evidence that information provision about polling place location plays a critical role in voters' turnout decisions. 
Table 6 - Effect of Polling Place Name (but not Location) Changes on Turnout, Wake County, Individual Level, 2008-2016.

\begin{tabular}{lcccccc}
\hline \hline & \multicolumn{2}{c}{ Voted } & \multicolumn{2}{c}{ Voted at Polling Place } & \multicolumn{2}{c}{ Voted Convenience } \\
& $(1)$ & $(2)$ & $(3)$ & $(4)$ & $(5)$ & $(6)$ \\
\hline PP Name Change & 0.061 & 0.018 & 0.054 & 0.022 & 0.007 & -0.004 \\
& $(0.052)$ & $(0.012)$ & $(0.013)$ & $(0.013)$ & $(0.052)$ & $(0.012)$ \\
\hline $\mathrm{N}$ & $5,146,719$ & $5,146,719$ & $5,146,719$ & $5,146,719$ & $5,146,719$ & $5,146,719$ \\
$\#$ Voters & 861,286 & 861,286 & 861,286 & 861,286 & 861,286 & 861,286 \\
Election FEs & No & Yes & No & Yes & No & Yes \\
\hline \hline
\end{tabular}

Note: Robust standard errors clustered by precinct in parentheses. The sample includes voters in Wake County, North Carolina whose polling place location remained the same between elections. The outcome in Columns 1 and 2 is a whether an individual voted in the general election, the outcome in Columns 3 and 4 is whether an individual voted at her polling place in the general election, and the outcome in Columns 5 and 6 is whether an individual voted using convenience methods in the general election. PP Name Change is an indicator for whether or not the name of the voter's assigned polling place was changed, which generates an informational mailer about the polling place location. The table shows that voters who received additional information about their polling place were more likely to vote at their polling place than those who did not receive the additional information.

\section{Conclusion}

In this paper, I have shown that polling place changes decrease general election turnout, and I show suggestive evidence that this decrease comes primarily through search costs rather than through transportation costs. Moreover, I find that declines in polling place turnout are concentrated among younger voters and non-homeowners, groups that we expect to be less likely to acquire information about polling place changes through the traditional means of communication used by counties to notify voters of these changes. This has important policy implications. If parties and other groups are interested in mitigating the turnout decline caused by polling place changes, they should provide information for and mobilize groups of voters that are less likely to acquire information through the modes of communication outlined by North Carolina's notification requirements. It also suggests that concerns over transportation costs are overblown relative to the confusion induced by polling place changes, at least in North Carolina.

To what extent can I generalize beyond the context of North Carolina? Unfortunately, other states do not offer both polling place lists going back many years along with voter file 
snapshots to match voters to polling places for many elections over time, so empirically it is difficult to say. Turnout decisions are admittedly context-specific, and North Carolina is a battleground state with a particularly unique set of election laws, from high availability of early voting options, same-day voter registration since 2007 (but only during the early voting period), and a host of other changes implemented in $2013 .{ }^{24}$. Nonetheless, the difference-indifferences design controls for unobservable characteristics that affect all counties similarly, like statewide changes to election administration. Because North Carolina offers a robust set of early and convenience voting options, I suspect that the demobilizing effect of polling place changes is smaller in North Carolina than in other states that do not offer similar early voting opportunities. This effect is meaningful: although there has been a trend away from in-person polling place voting in U.S. election administration, 22 states still do not offer no-excuse absentee voting by mail. ${ }^{25} 12$ states do not offer any early voting opportunities without an excuse, including many Southern states. I show evidence in this paper that voters facing polling place changes substitute toward other forms of voting options, so while many states do not offer similar convenience voting opportunities, the effect I estimated has important policy implications.

This information mechanism could also matter for election reforms beyond polling place changes. Of course, this study is limited in its focus on one specific type of change - the location of polling places - so the empirics cannot speak directly to the effects of many statewide election reforms like no-excuse absentee voting, registration requirements, sameday registration, or voter ID laws. Nonetheless, the information mechanism outlined in this article might extend to other areas of election reform like registration requirements, early voting opportunities, and voter ID laws, which would be consistent with previous work on information provision to reduce barriers to voting (e.g., Fraga 2018). When states either impose or lessen voting costs through changes to election administration, voters must acquire information about these changes. In the case of voter ID laws, voters must acquire

\footnotetext{
${ }^{24}$ https://www.ncleg.net/Sessions/2013/Bills/House/PDF/H589v8.pdf

${ }^{25}$ http://www.ncsl .org/research/elections-and-campaigns/absentee-and-early-voting.aspx.
} 
information about what type of identification is acceptable to be able to vote and how they can acquire an acceptable form of identification. For election reforms designed to expand voting opportunities, like early in-person voting, voters must acquire information about the location of early voting centers along with their days and hours of operation. Therefore, the evidence for the informational mechanism in this paper likely extends to many of the statewide election reforms, where estimating causal effects has been a methodological challenge for researchers. Overall, the evidence in this paper suggests that providing information to voters is an important way to increase turnout in the face of informationally costly election reforms. 


\section{References}

Aldrich, John H. 1993. "Rational Choice and Turnout." American Journal of Political Science pp. 246-278.

Alvarez, R Michael, Delia Bailey, and Jonathan N Katz. 2008. The Effect of Voter Identification Laws on Turnout. Technical Report 1267R California Institute of Technology Social Science Working Paper Series.

Alvarez, R Michael, Ines Levin, and J Andrew Sinclair. 2012. "Making Voting Easier: Convenience Voting in the 2008 Presidential Election." Political Research Quarterly 65(2): 248-262.

Amos, Brian, Daniel A Smith, and Casey Ste Claire. 2017. "Reprecincting and Voting Behavior." Political Behavior 39(1): 133-156.

Angrist, Joshua D, and Jörn-Steffen Pischke. 2008. Mostly Harmless Econometrics: An Empiricist's Companion. Princeton University Press.

Autor, David H. 2003. "Outsourcing at Will: The Contribution of Unjust Dismissal Doctrine to the Growth of Employment Outsourcing." Journal of Labor Economics 21(1): 1-42.

Avery, James M, and Mark Peffley. 2005. "Voter Registration Requirements, Voter Turnout, and Welfare Eligibility Policy: Class Bias Matters." State Politics $\& 3$ Policy Quarterly 5(1): $47-67$.

Berinsky, Adam J. 2005. "The Perverse Consequences of Electoral Reform in the United States." American Politics Research 33(4): 471-491.

Blais, André. 2000. To Vote or Not to Vote?: The Merits and Limits of Rational Choice Theory. University of Pittsburgh Press.

Brady, Henry E, and John E McNulty. 2011. "Turning Out to Vote: The Costs of Finding and Getting to the Polling Place." American Political Science Review 105(01): 115-134.

Burden, Barry C, David T Canon, Kenneth R Mayer, and Donald P Moynihan. 2014. "Election Laws, Mobilization, and Turnout: The Unanticipated Consequences of Election Reform." American Journal of Political Science 58(1): 95-109.

Clinton, Joshua D, Nick Eubank, Adriane Fresh, and Michael E Shepherd. N.d. "Polling Place Changes and Political Participation: Evidence from North Carolina Presidential Elections, 2008-2016." . Forthcoming. 
De Alth, Shelley. 2009. "ID at the Polls: Assessing the Impact of Recent State Voter ID Laws on Voter Turnout.".

Downs, Anthony. 1957. "An Economic Theory of Political Action in a Democracy." The Journal of Political Economy pp. 135-150.

Dropp, Kyle. 2013. "Voter Identification Laws and Voter Turnout." Unpublished paper .

Erikson, Robert S, and Lorraine C Minnite. 2009. "Modeling Problems in the Voter Identification-Voter Turnout Debate." Election Law Journal 8(2): 85-101.

Feddersen, Timothy, and Alvaro Sandroni. 2006. "A Theory of Participation in Elections." American Economic Review 96(4): 1271-1282.

Feddersen, Timothy J. 2004. "Rational Choice Theory and the Paradox of Not Voting." Journal of Economic Perspectives pp. 99-112.

Feddersen, Timothy J, and Wolfgang Pesendorfer. 1999. "Abstention in Elections with Asymmetric Information and Diverse Preferences." American Political Science Review 93(2): 381-398.

Fitzgerald, Mary. 2005. "Greater Convenience But Not Greater Turnout: The Impact of Alternative Voting Methods on Electoral Participation in the United States." American Politics Research 33(6): 842-867.

Fowler, Anthony. 2017. "Does Voter Preregistration Increase Youth Participation?" Election Law Journal: Rules, Politics, and Policy 16(4): 485-494.

Fraga, Bernard L. 2018. The Turnout Gap: Race, Ethnicity, and Political Inequality in a Diversifying America. Cambridge University Press.

Francia, Peter L, and Paul S Herrnson. 2004. "The Synergistic Effect of Campaign Effort and Election Reform on Voter Turnout in State Legislative Elections." State Politics \& Policy Quarterly 4(1): 74-93.

Giammo, Joseph D, and Brian J Brox. 2010. "Reducing the Costs of Participation: Are States Getting a Return on Early Voting?" Political Research Quarterly 63(2): 295-303.

Gimpel, James G, and Jason E Schuknecht. 2003. "Political Participation and the Accessibility of the Ballot Box." Political Geography 22(5): 471-488.

Green, Donald, and Ian Shapiro. 1996. Pathologies of Rational Choice Theory: A Critique of Applications in Political Science. Yale University Press. 
Grimmer, Justin, Eitan Hersh, Marc Meredith, Jonathan Mummolo, and Clayton Nall. 2018. "Obstacles to Estimating Voter ID Lawsâ Effect on Turnout." The Journal of Politics 80(3): 000-000.

Gronke, Paul, Eva Galanes-Rosenbaum, and Peter A Miller. 2007. "Early Voting and Turnout." PS: Political Science 83 Politics 40(04): 639-645.

Hajnal, Zoltan, Nazita Lajevardi, and Lindsay Nielson. 2017. "Voter Identification Laws and the Suppression of Minority Votes." The Journal of Politics 79(2): 363-379.

Hanmer, Michael J. 2009. Discount Voting: Voter Registration Reforms and Their Effects. Cambridge University Press.

Hasen, Richard L. 2012. The Voting Wars: From Florida 2000 to the Next Election Meltdown. Yale University Press.

Haspel, Moshe, and H Gibbs Knotts. 2005. "Location, Location, Location: Precinct Placement and the Costs of Voting." Journal of Politics 67(2): 560-573.

Holbein, John B, and D Sunshine Hillygus. 2016. "Making Young Voters: The Impact of Preregistration on Youth Turnout." American Journal of Political Science 60(2): 364-382.

Huckfeldt, Robert, and John Sprague. 1992. "Political Parties and Electoral Mobilization: Political Structure, Social Structure, and the Party Canvass." American Political Science Review 86(1): 70-86.

Larocca, Roger, and John S Klemanski. 2011. "US State Election Reform and Turnout in Presidential Elections." State Politics 83 Policy Quarterly 11(1): 76-101.

Leighley, Jan E, and Jonathan Nagler. 2007. "Unions, Voter turnout, and Class Bias in the US Electorate, 1964-2004." The Journal of Politics 69(2): 430-441.

Leighley, Jan E, and Jonathan Nagler. 2013. Who Votes Now?: Demographics, Issues, Inequality, and Turnout in the United States. Princeton University Press.

McNulty, John E, Conor M Dowling, and Margaret H Ariotti. 2009. "Driving Saints to Sin: How Increasing the Difficulty of Voting Dissuades Even the Most Motivated Voters." Political Analysis 17(4): 435-455.

Morton, Rebecca B. 1991. "Groups in Rational Turnout Models." American Journal of Political Science pp. 758-776. 
Mycoff, Jason D, Michael W Wagner, and David C Wilson. 2009. "The Empirical Effects of Voter-ID Laws: Present or Absent?" PS: Political Science $\&$ Politics 42(01): 121-126.

Niemi, Richard G. 1976. "Costs of Voting and Nonvoting." Public Choice 27(1): 115-119.

Oliver, J Eric. 1996. "The Effects of Eligibility Restrictions and Party Activity on Absentee Voting and Overall Turnout." American Journal of Political Science pp. 498-513.

Riker, William H, and Peter C Ordeshook. 1968. "A Theory of the Calculus of Voting." American Political Science Review 62(01): 25-42.

Riker, William H, and Peter C Ordeshook. 1973. An Introduction to Positive Political Theory. Vol. 387 Prentice-Hall Englewood Cliffs, NJ.

Rosenstone, Steven J, and John Hansen. 1993. Mobilization, Participation, and Democracy in America. Macmillan Publishing Company.

Sanders, Elizabeth. 1980. "On the Costs, Utilities and Simple Joys of Voting." The Journal of Politics pp. 854-863.

Shachar, Ron, and Barry Nalebuff. 1999. "Follow the Leader: Theory and Evidence on Political Participation." American Economic Review 89(3): 525-547.

Stein, Robert M, and Greg Vonnahme. 2008. "Engaging the Unengaged Voter: Vote Centers and Voter Turnout." The Journal of Politics 70(2): 487-497.

Uhlaner, Carole J. 1989. "Rational Turnout: The Neglected Role of Groups." American Journal of Political Science pp. 390-422.

Verba, Sidney, Kay Lehman Schlozman, and Henry E Brady. 1995. Voice and Equality: Civic Voluntarism in American Politics. Harvard University Press.

Vercellotti, Timothy, and David Anderson. 2006. "Protecting the Franchise, or Restricting It? The Effects of Voter Identification Requirements on Turnout.".

Wolfinger, Raymond E, and Steven J Rosenstone. 1980. Who Votes? Vol. 22 Yale University Press.

Wolfinger, Raymond E, Benjamin Highton, and Megan Mullin. 2005. "How Postregistration Laws Affect the Turnout of Citizens Registered to Vote." State Politics 83 Policy Quarterly 5(1): $1-23$. 


\section{Online Appendix}

Intended for online publication only.

\section{Contents}

A.1 Unifying the Results with Existing Research . . . . . . . . . . . . . . . 34

A.1.1 The Effect of Polling Place Changes on Turnout in Presidential Elections . . . . . . . . . . . . . . . . . . . 35

A.1.2 The Effect of Polling Place Distance Changes on Turnout in Presidential Elections . . . . . . . . . . . . . . . . . . 36

A.1.3 Differential Effects of Polling Place Changes by Race . . . . . . . . 37

A.2 Separating Search and Distance Costs of Polling Place Changes . . . . . . . 39

A.3 Validating the Parallel Trends Assumption . . . . . . . . . . . . . . . . . 44

A.4 Assembling the North Carolina Analysis Dataset . . . . . . . . . . . . . 45

A.5 Other Tables and Figures . . . . . . . . . . . . . . . . 48 


\section{A.1 Unifying the Results with Existing Research}

Clinton et al. (N.d.) estimates the effects of polling place changes in North Carolina using slightly different data, which creates a unique opportunity to aggregate evidence across our two studies to learn more about how polling place changes affect voter turnout. In this section, I compare my results to three main findings in Clinton et al. (N.d.), and I use these comparisons to illustrate how polling place changes might affect voters in different ways depending on the voter's characteristics and the electoral context. Specifically, three of the main findings in Clinton et al. (N.d.) are (1) that polling place changes have no effect on overall turnout, on average, but they do reduce Election Day turnout and cause a substitution toward early voting, and (2) that voters consider changes in polling place distance when choosing their vote method, and (3) that there is at least suggestive evidence of potential differential effects of polling place changes by race.

I come to one main conclusion from the analyses below. When I use a similar differencein-differences design but include a longer panel that includes non-presidential years, I find that polling place changes cause a 1 to 2 percentage point decline in overall turnout, on average. This finding differs slightly from Clinton et al. (N.d.), but I obtain results quite similar to theirs when I zoom in on presidential elections in 2012 and 2016, as they do. This highlights the importance of aggregating information across these two studies to understand more about how and when voters might be affected by polling place changes.

From the analyses below, I also generate two other conclusions. First, while voters certainly take distance from their polling place into account when deciding whether to vote on Election Day or using convenience voting options, using my difference-in-differences design I find that changes in distance from one's polling place do not seem to differentially affect

turnout. Rather, the search costs that voters incur from the polling place change itself reduces their turnout likelihood regardless of how the polling place distance has changed, at least in North Carolina. Second, I do not find differential effects of polling place changes by race, but I do find that vote method substitution in response to polling place changes is particularly concentrated among older voters and homeowners.

In the following subsections, I compare results across the two studies and elaborate on some of the key differences between the two datasets, which could help explain some of the differences in results. 


\section{A.1.1 The Effect of Polling Place Changes on Turnout in Presi- dential Elections}

To begin, I compare my results to the presidential elections results from Clinton et al. (N.d.). The setup is very similar: both studies use change in polling place as the treatment variable and voting (overall, Election Day, and early) as the outcome. However, there are a few key differences in the two datasets. Clinton et al. (N.d.) define the polling place change treatment variable as whether a voter had their polling place changed from the last presidential election. For example, for 2012 a voter is coded as having their polling place changed if their polling place is different from their assigned polling place in the 2008 presidential election. Because I have a panel of polling place assignments in both midterm and presidential election years, my polling place change variable is whether a voter had their polling place changed from the general election two years ago. So, for example, for 2012 a voter is coded as having their polling place change if their polling place is different from their assigned polling place in the 2010 general election. Fortunately, I can reconstruct the polling place change variable from Clinton et al. (N.d.) and subset just to presidential elections, as they do. Following their specification, I also include race-by-year fixed effects in my replication. ${ }^{26}$ The results are shown in Table A.1, and they are remarkably similar to those in estimated in Clinton et al. (N.d.). For example, the point estimate in column 1 is nearly exactly the same as the one in the main text in Clinton et al. (N.d.), and I also see the pattern of substitution away from polling place voting and toward early voting - although the magnitude of the substitution is slightly smaller in my data than in Clinton et al. (N.d.). One reason for this could be that our original data is constructed slightly differently. Clinton et al. (N.d.) have statewide coverage because their polling place locations were collected for presidential election years from the North Carolina State Board of Elections. To get a longer and more fine-grained panel of polling place changes, I collected polling place locations for every primary and general election from 2006-2016 from individual North Carolina County Boards of Elections. I describe in more detail how I assembled the dataset in section A.4 of the Appendix.

I should also note that the finding here differs slightly from my main result in Table 2, where I find that polling place changes cause between a 1 and 2 percentage point decline in overall general election turnout. One of the advantages of the design that I use for Table 2 is that it includes non-presidential election years, so for the full sample (in column 1 of Table 2 , for example), the treatment variable represents a change within two years since the last election instead of four. For example, it could be that voters who have their polling place

${ }^{26}$ Clinton et al. (N.d.) also subset to voters whose registration address and polling place are both able to be geocoded in each year, so I also do that for this analysis. 
Table A.1 - Effect of Polling Place Changes on Presidential Election Turnout, Individual Level, 2012-2016.

\begin{tabular}{|c|c|c|c|}
\hline & $\begin{array}{l}\text { Voted } \\
(1)\end{array}$ & $\begin{array}{l}\text { Voted at Polling Place } \\
(2)\end{array}$ & $\begin{array}{c}\text { Voted Convenience } \\
(3)\end{array}$ \\
\hline \multirow[t]{2}{*}{ PP Change } & 0.002 & -0.009 & 0.011 \\
\hline & $(0.002)$ & $(0.007)$ & $(0.007)$ \\
\hline $\mathrm{N}$ & $2,456,417$ & $2,456,417$ & $2,456,417$ \\
\hline \# Voters & $1,392,296$ & $1,392,296$ & $1,392,296$ \\
\hline Race-by-Year FEs & Yes & Yes & Yes \\
\hline Voter FEs & Yes & Yes & Yes \\
\hline
\end{tabular}

Note: Robust standard errors clustered by precinct in parentheses.

The outcome in Column 1 is a whether an individual voted in the general election, the outcome in Column 2 is whether an individual voted at her polling place in the general election, and the outcome in Column 3 is whether an individual voted using convenience methods in the general election.

changed in 2009 have many elections or other opportunities to locate their new polling place before the 2012 presidential election, so they might be less affected by polling place changes than voters who have their polling place changed just before the 2012 election. In fact, I do find some evidence for this - because I have collected polling place lists for primary elections as well, I can estimate the effect of polling place changes on turnout for those who had their polling place changed between the primary and general election in any given year. I find that, even for high-propensity voters who turn out in primary elections, polling place changes between the primary and general election cause nearly a 2 percentage point decline in overall turnout (see column 2 of Table 2).

\section{A.1.2 The Effect of Polling Place Distance Changes on Turnout in Presidential Elections}

After examining the overall effects, I can now explore the evidence from both Clinton et al. (N.d.) and my study on some interesting heterogeneous effects based on changes in distance from one's polling place. Specifically, Clinton et al. (N.d.) finds that the substitution away from Election Day voting and toward early voting depends not only on the polling place change itself, but also on the change in the voter's distance from their polling place. Consistent with Clinton et al. (N.d.), I find that the effect of polling place changes on overall turnout does not seem to depend on changes in polling place distance. In Table A.3 in the Appendix I also include a specification where polling place distance is included as a control 
variable, and it suggests that voters certainly consider the distance from their Election Day polling place when deciding whether to vote at their polling place or use conveience voting options. To identify the effect of polling place changes across different changes in distance, I construct distance change deciles for those experiencing a polling place change, and I then estimate the effect of polling place changes separately for each distance change decile. Using this design, polling place distance changes do not seem to differentially alter the effect of polling place changes on Election Day turnout (see Figure 3).

\section{A.1.3 Differential Effects of Polling Place Changes by Race}

Lastly, Clinton et al. (N.d.) includes cross-sectional estimates of the polling place change variable interacted with an individual-level indicator of the voter's race, finding that nonwhite voters exhibit less vote method substitution in response to polling place changes than do white voters. In Table A.2 I replicate this Clinton et al. (N.d.) finding using my data. Consistent with their result, the interaction coefficients suggest that non-whites are more likely to continue voting on Election Day and less likely to substitute toward convenience voting when facing a polling place change. As Clinton et al. (N.d.) notes, however, these estimates should be interpreted with some caution. These results could reflect subtle changes to early voting availability by county that differentially affect voters by race. Because polling place changes do not occur at random, one concern would be that polling place changes are happening in areas where convenience voting is becoming less attractive for minority voters. To help identify differential effects of polling place changes by race, I estimate my original difference-in-differences specification from equation 1, but I include an interaction term of polling place change with whether a voter is listed as Black in the voter file. Using this design, in Table A.10, I find that polling place changes decrease overall turnout by about 1.1 percentage points among non-Black voters, and by about 1.6 percentage points among Black voters, although the difference in effects is estimated somewhat imprecisely. ${ }^{27}$

More generally, both sets of results help speak to the possibility of heterogeneous effects of polling place changes. For example, Clinton et al. (N.d.) shows that the partial correlation between polling palce changes and early voting does not depend meaningfully on the number of early voting locations in a county. In section 4.2, I interact the polling place change indicator with individual-level measures of age and homeownership, and I find that substitution toward convenience voting in response to polling place changes is primarily concentrated among older voters and homeowners. The use of fine-grained, individual-level

${ }^{27}$ The 1.6 percentage point decrease is the sum of PP Change and PP Change $*$ Black. The main effect for Black is absorbed by the voter fixed effects. 
Table A.2 - Correlates of Presidential Election Turnout, Individual Level by Race, 2012-2016.

\begin{tabular}{lcccccc}
\hline \hline & \multicolumn{2}{c}{ Voted } & \multicolumn{2}{c}{ Voted at Polling Place } & \multicolumn{2}{c}{ Voted Convenience } \\
& $(1)$ & $(2)$ & $(3)$ & $(4)$ & $(5)$ & $(6)$ \\
\hline PP Change & -0.008 & -0.000 & -0.023 & -0.040 & 0.015 & 0.040 \\
& $(0.009)$ & $(0.007)$ & $(0.009)$ & $(0.009)$ & $(0.008)$ & $(0.009)$ \\
PP Change $\times$ Non-White & 0.000 & -0.019 & 0.011 & 0.016 & -0.011 & -0.034 \\
& $(0.012)$ & $(0.008)$ & $(0.008)$ & $(0.009)$ & $(0.012)$ & $(0.011)$ \\
Non-White & 0.003 & -0.019 & -0.092 & -0.066 & 0.095 & 0.046 \\
& $(0.004)$ & $(0.003)$ & $(0.003)$ & $(0.003)$ & $(0.004)$ & $(0.004)$ \\
\hline $\mathrm{N}$ & $1,408,209$ & $1,082,532$ & $1,408,209$ & $1,082,532$ & $1,408,209$ & $1,082,532$ \\
Year Sample & 2012 & 2016 & 2012 & 2016 & 2012 & 2016 \\
Individual Controls & Yes & Yes & Yes & Yes & Yes & Yes \\
\hline \hline
\end{tabular}

Note: Robust standard errors clustered by precinct in parentheses. The outcome in Columns 1 and 2 is a whether an individual voted in the general election, the outcome in Columns 3 and 4 is whether an individual voted at her polling place in the general election, and the outcome in Columns 5 and 6 is whether an individual voted using convenience methods in the general election. Individual level controls are indicators for party registration, age, and age squared.

administrative data in both studies can help us understand more deeply how disruptions to Election Day voting might differentially affect certain types of voters. 


\section{A.2 Separating Search and Distance Costs of Polling Place Changes}

Brady and McNulty (2011) provides a useful model for considering how voters make choices over polling place voting, convenience voting, and abstention. Define the utility of person $i$ from voting at her polling place $p$ to be $U_{i}^{p}$, and the utility from voting absentee or convenience $U_{i}^{a}$. Normalizing the utility of not voting to zero, individual $i$ votes if her utility from polling place voting exceeds the utility from abstention, $U_{i}^{p} \geq 0$, or if her utility from absentee voting exceeds the utility from abstention, $U_{i}^{a} \geq 0$. If both conditions are satisfied, the individual votes at her polling place rather than using convenience methods if her utility of polling place voting at the polling place exceeds that of absentee voting $\left(U_{i}^{p} \geq U_{i}^{a}\right)$. $U_{i}^{a}$ can be written as $b_{i}-c_{i}^{a}$, where $b$ represents the benefits to voting and $c^{a}$ represents the costs of absentee voting. Similarly, $U_{i}^{p}=b_{i}-c_{i}^{p}$, where $c^{p}$ is the cost of polling place voting. Here, I extend the Brady and McNulty (2011) slightly to illustrate how individuals might vary in their sensitivity to polling place changes. I decompose the polling place cost $c^{p}$ into a "search" component and a "distance" component, and allow these costs to vary by individual $\left(c_{i}^{p}=s_{i}+\gamma_{i} d\right)$. Thus, individuals can vary in their ability to acquire information about polling place changes $s_{i}$. As noted earlier, in North Carolina voters are notified about polling place changes via mail, newspaper, and possibly radio and television. Therefore, the costs of acquiring information about polling place changes will be lower for individuals who receive information from these sources. Individuals might also vary in their sensitivity to polling place distance $\gamma_{i}$. For example, one might expect the marginal cost of traveling an additional mile to a polling place to be higher for those without access to a car or other mode of transportation. Both of these components have observable implications: first, we might expect older or higher income voters, types we might expect to receive information through tradtional media sources, to be less sensitive to the search costs associated with polling place changes. Second, we might expect that voters in densely populated areas, where voters are less likely to use cars to travel to their polling place, are more sensitive to distance costs associated with polling place changes.

Figure A.1 provides a graphical depiction of how voters respond to polling place changes. On the $\mathrm{x}$-axis is distance from polling place, and on the $\mathrm{y}$-axis is the voter's utility. The left panel shows a potential "switcher," or individual whose net benefit of voting absentee exceeds the net benefit of not voting. For these types of voters, the decision is about vote method because utility of voting absentee is constant across polling place distance and is greater than 0 . The utility of voting at the polling place, $U^{p}=b-s-\gamma d$, can be represented very simply graphically. The intercept is $b-s$ (or $b$ when a voter does not face a polling 


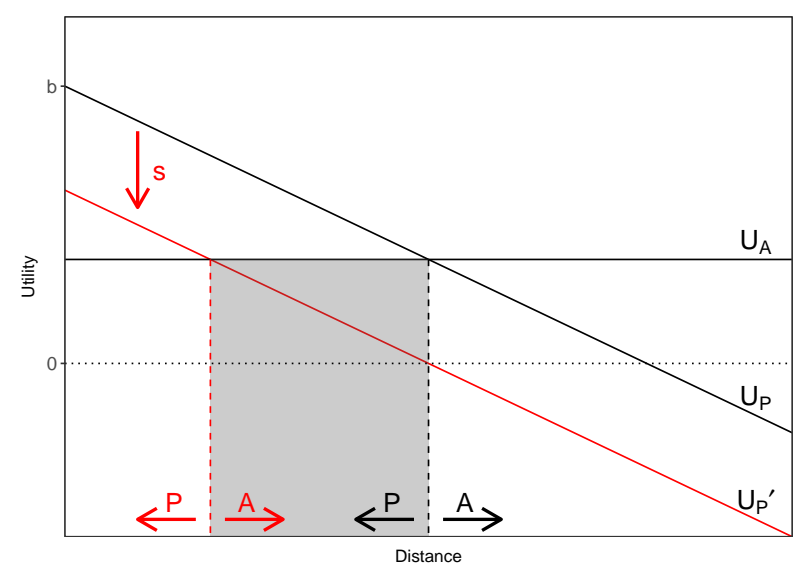

(a) Switchers

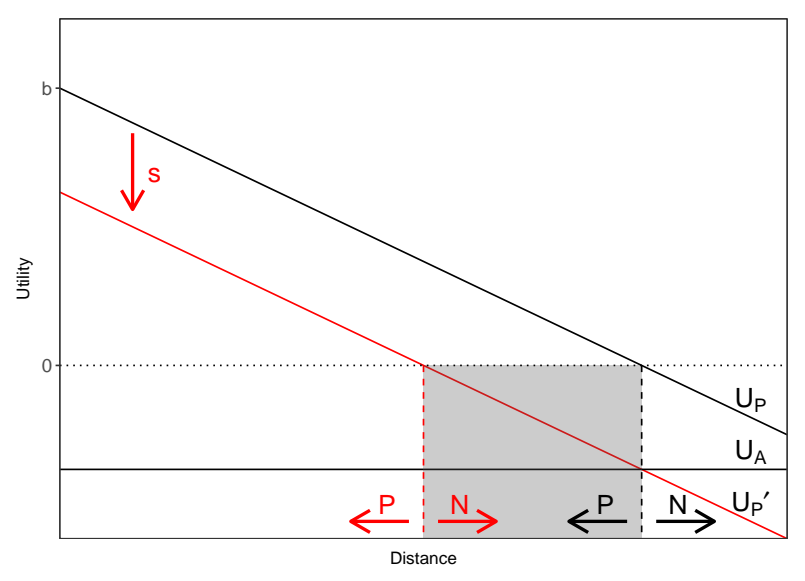

(b) Abstainers

Figure A.1 - Theory of Polling Place Search and Distance Costs

This figure shows two possible effects of polling place changes. The left panel shows potential "switchers," voters for whom the net benefit of voting absentee exceeds the net benefit of abstaining. When this type of voter faces the search costs associated with a polling place change, she becomes less likely on average to vote at her polling place and more likely to vote using convenience methods (represented by the gray shaded box). The right panel shows potential "abstainers," voters for whom the net benefit of voting absentee is less than the net benefit of abstaining. When this type of voter faces a polling place change, she becomes less likely to vote at her polling place and more likely to abstain from voting (again, represented by the gray shaded box).

place change because the search cost $s$ is 0 ), and the slope of the utility function is $\gamma$, or the sensitivity of the voter to distance from polling place. When $\gamma$ is high, the voter is especially averse to traveling long distances to their polling place. ${ }^{28} \mathrm{~A}$ voter in the left panel votes absentee if she is sufficiently far from her polling place and votes at her polling place if she is sufficiently close to her polling place. When a voter's polling place is changed, her utility of voting at the polling place shifts down vertically by the search cost $s$, represented by the red line. For potential switchers, it is clear that, on average, we should observe voters facing polling place location changes to use convenience voting methods at higher rates than those without polling place changes. ${ }^{29}$ The right panel shows a potential "abstainer," that is, an individual whose net benefit of voting absentee is lower than the net benefit of abstaining. We should observe that overall turnout among voters of this type will be lower on average among those faced with polling place changes compared to those that do not.

\footnotetext{
${ }^{28}$ For example, this could be a voter without access to a convenient mode of transportation, or an individual that does not like to travel to a possibly unfamiliar neighborhood to vote.

${ }^{29}$ This assumes that polling place changes do not decrease voters' distances to their polling place on average, which I show evidence for in Figure 2
} 
Table A.3 - Effect of Polling Place Changes on General Election Turnout, Individual Level, 2008-2016.

\begin{tabular}{|c|c|c|c|c|c|c|}
\hline \multirow[b]{2}{*}{ Sample } & \multicolumn{2}{|r|}{ Voted } & \multicolumn{2}{|c|}{ Voted at Polling Place } & \multicolumn{2}{|c|}{ Voted Convenience } \\
\hline & $\begin{array}{c}\text { Full } \\
(1)\end{array}$ & $\begin{array}{c}\text { Primary Voters } \\
(2)\end{array}$ & $\begin{array}{l}\text { Full } \\
(3)\end{array}$ & $\begin{array}{c}\text { Primary Voters } \\
\text { (4) }\end{array}$ & $\begin{array}{l}\text { Full } \\
(5)\end{array}$ & $\begin{array}{c}\text { Primary Voters } \\
(6)\end{array}$ \\
\hline \multirow[t]{2}{*}{ PP Change } & -0.008 & -0.018 & -0.011 & -0.028 & 0.002 & 0.010 \\
\hline & $(0.002)$ & $(0.008)$ & $(0.003)$ & $(0.020)$ & $(0.003)$ & $(0.017)$ \\
\hline \multirow[t]{2}{*}{ PP Distance } & -0.003 & -0.003 & -0.009 & -0.024 & 0.006 & 0.021 \\
\hline & $(0.002)$ & $(0.002)$ & $(0.002)$ & $(0.006)$ & $(0.003)$ & $(0.006)$ \\
\hline $\mathrm{N}$ & $8,556,203$ & $1,611,680$ & $8,556,203$ & $1,611,680$ & $8,556,203$ & $1,611,680$ \\
\hline \# Voters & $2,519,197$ & 791,098 & $2,519,197$ & 791,098 & $2,519,197$ & 791,098 \\
\hline Election FEs & Yes & Yes & Yes & Yes & Yes & Yes \\
\hline Voter FEs & Yes & Yes & Yes & Yes & Yes & Yes \\
\hline \multicolumn{7}{|c|}{$\begin{array}{l}\text { Note: Robust standard errors clustered by precinct in parentheses. The outcome in Columns } 1 \text { and } \\
2 \text { is a whether an individual voted in the general election, the outcome in Columns } 3 \text { and } 4 \text { is whether } \\
\text { an individual voted at her polling place in the general election, and the outcome in Columns } 5 \text { and } \\
6 \text { is whether an individual voted using convenience methods in the general election. PP Change is a } \\
\text { binary variable indicating whether an individual had her Election Day polling place location changed } \\
\text { from the previous general election (or from the primary election for the primary sample). PP Distance } \\
\text { is the individual's distance from her Election Dav polling place. }\end{array}$} \\
\hline
\end{tabular}

Table A.3 includes whether or not the the polling place was changed as well as the polling place distance in miles as right-hand side variables, which is designed to estimate the effect of polling place changes after controlling for the voter's distance from their polling place. The first two columns suggest that the majority of the voting costs imposed by polling place changes come in the form of search costs rather than transportation costs. In the full sample, for example, the search cost component decreases turnout by about 0.8 percentage points. Meanwhile, the coefficient on polling place distance is statistically indistinguishable from zero. Columns 3 through 6 help illuminate the role of polling place distance in the turnout decision. Each additional mile in polling place distance is associated with a decrease in the likelihood of voting at one's polling place of about 0.9 percentage points, but it is positively associated with one's likelihood of voting using convenience methods. The role of distance in vote method substitution is even stronger in the sample that subsets on primary voters. Mapping this result back to the theory in Figure A.1, it appears that the sensitivity to polling place distance, is higher for potential switchers than for potential abstainers. The results suggest that, at least in a state with a robust set of convenience voting options like North Carolina, distance costs matter very little for turnout. Potential abstainers seem to abstain because of search costs rather than distance costs, while potential switchers are the ones who use polling place distance to determine their vote method choice rather than their turnout decision. 
In Table A.4 I show that the results are similar when using Manhattan distance instead of Euclidean distance. In Figure A.2, I show that the results show in Figure 3 in the main text are similar when using Manhattan distance.

\section{Table A.4 - Effect of Polling Place Changes on General Election Turnout, Individual Level, 2008-2016.}

\begin{tabular}{|c|c|c|c|c|c|c|}
\hline \multirow[b]{2}{*}{ Sample } & \multicolumn{2}{|r|}{ Voted } & \multicolumn{2}{|c|}{ Voted at Polling Place } & \multicolumn{2}{|c|}{ Voted Convenience } \\
\hline & $\begin{array}{c}\text { Full } \\
(1)\end{array}$ & $\begin{array}{c}\text { Primary Voters } \\
(2)\end{array}$ & $\begin{array}{l}\text { Full } \\
(3)\end{array}$ & $\begin{array}{c}\text { Primary Voters } \\
\text { (4) }\end{array}$ & $\begin{array}{c}\text { Full } \\
(5)\end{array}$ & $\begin{array}{c}\text { Primary Voters } \\
(6)\end{array}$ \\
\hline \multirow[t]{2}{*}{ PP Change } & -0.009 & -0.018 & -0.011 & -0.027 & 0.002 & 0.010 \\
\hline & $(0.002)$ & $(0.008)$ & $(0.003)$ & $(0.020)$ & $(0.003)$ & $(0.017)$ \\
\hline \multirow[t]{2}{*}{ PP Distance (Manhattan) } & -0.002 & -0.003 & -0.007 & -0.022 & 0.006 & 0.019 \\
\hline & $(0.001)$ & $(0.002)$ & $(0.002)$ & $(0.005)$ & $(0.002)$ & $(0.005)$ \\
\hline $\mathrm{N}$ & $8,533,250$ & $1,608,055$ & $8,533,250$ & $1,608,055$ & $8,533,250$ & $1,608,055$ \\
\hline \# Voters & $2,513,710$ & 789,293 & $2,513,710$ & 789,293 & $2,513,710$ & 789,293 \\
\hline Election FEs & Yes & Yes & Yes & Yes & Yes & Yes \\
\hline Voter FEs & Yes & Yes & Yes & Yes & Yes & Yes \\
\hline
\end{tabular}

Note: Robust standard errors clustered by precinct in parentheses. The outcome in Columns 1 and 2 is a whether an individual voted in the general election, the outcome in Columns 3 and 4 is whether an individual voted at her polling place in the general election, and the outcome in Columns 5 and 6 is whether an individual voted using convenience methods in the general election. The full sample includes all voters and the primary sample subsets to individuals who voted in the primary election in the present year. PP Change is a binary variable indicating whether an individual had her Election Day polling place location changed from the previous general election (or from the primary election for the primary sample). PP Distance is the individual's Manhattan distance from her Election Day polling place. 


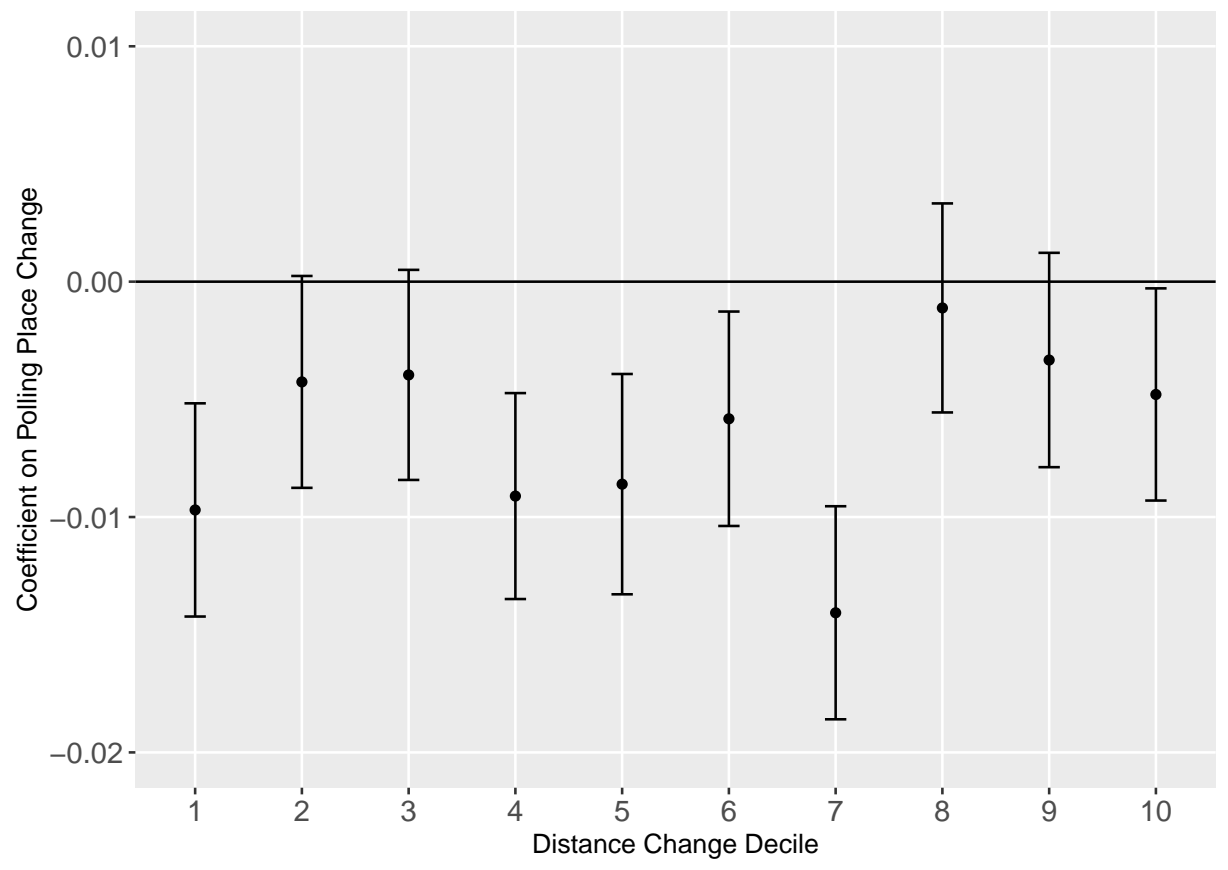

Figure A.2 - Effect of Polling Place Change Across Distance Change

This figure shows coefficient estimates of the effect of polling place changes on turnout across changes in polling place distance, using Manhattan distance to compute distance change deciles. The $\mathrm{x}$-axis is the decile of the change in distance from one's polling place. Each point represents a coefficient estimate from the specification in Column 1 of Table A.4, but using only those within distance change decile as the treatment group. There appears to be no systematic relationship between change in polling place distance and the effect of polling place changes, suggesting that most of the effect can be attributed to search costs rather than transportations costs. 


\section{A.3 Validating the Parallel Trends Assumption}

In this section I show a series of tests to validate the parallel trends assumption. I focus on the main analysis of the effect of polling place changes on turnout in general elections, as shown in Table 2.

Table A.5 - Validating the Parallel Trends Assumption for Turnout Analysis

\begin{tabular}{lccccc}
\hline \hline & & & Voted & & $(5)$ \\
\hline PP Change & $(1)$ & $(2)$ & $(3)$ & $(4)$ & -0.011 \\
& -0.011 & -0.012 & -0.009 & -0.011 & $(0.002)$ \\
PP Change, t +1 & $(0.002)$ & $(0.002)$ & $(0.002)$ & $(0.002)$ & \\
& 0.002 & & & & \\
\hline N & $(0.003)$ & & & & $12,420,356$ \\
$\#$ Voters & $12,663,312$ & $12,673,951$ & $12,626,296$ & $12,673,951$ & 15,803 \\
Voter FEs & $3,223,219$ & $3,228,194$ & $3,224,459$ & $3,228,544$ & $3,155,85$ \\
Election FEs & Yes & Yes & Yes & Yes & Yes \\
County-Election FEs & Yes & No & No & No & No \\
County-Age-Election FEs & No & Yes & No & No & No \\
County-Party-Election FEs & No & No & Yes & No & No \\
County-Race-Election FEs & No & No & No & Yes & No \\
\hline \hline
\end{tabular}

Note: Robust standard errors clustered by precinct in parentheses.

First, I include a lead of the polling place change variable, where it takes on a value of 1 if the individual will experience a polling place change in the next time period. A coefficient far from zero on the lead coefficient would suggest that there is pre-trending. In column 1 of Table A.5, the coefficient on main effect of polling place changes remains similar to the estimate in column 1 of Table 2, and the coefficient on the lead is substantively small and statistically indistinguishable from zero. This is preliminary evidence that the parallel trends assumption likely holds.

Second, I vary the fixed effects in a variety of ways to adjust the implied counterfactual time trends. In column 2 I include county-by-election fixed effects, which constructs counterfactual trends based on individuals living within the same county. In column 3 I include county-by-party-by-election fixed effects, which uses individuals within the same county and of the same political party as the counterfactual trend. Lastly, in column 4 I include countyby-race-by-election fixed effects, which uses individuals within the same county and of the race as the counterfactual trend. The estimates using these different fixed effects remain largely unchanged from that in column 1 of Table 2 , which provides more evidence that the parallel trends assumption is satisfied. 
Figure A.3 - Dynamic Effect of Polling Place Changes on Turnout

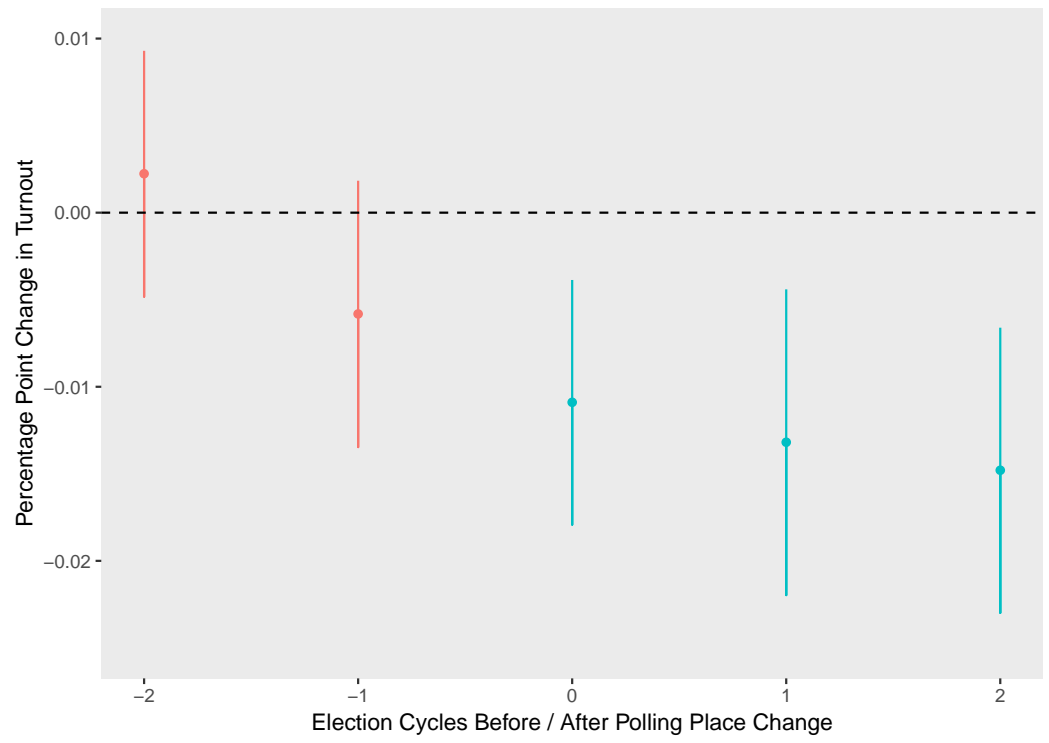

Note: In this analysis, I construct two leads of the polling place change variable, a switching indicator, and two lags of the polling place change variable. The two-period lead, for example, takes on a value of 1 if the individual is 2 election cycles away from having their polling place changed and zero otherwise.

Third, in Figure A.3 I include several leads and lags of polling place changes, modeling the dynamic effect of polling place changes on turnout (Autor 2003; Angrist and Pischke 2008). I construct two leads of the polling place change variable, a switching indicator, and two lags of the polling place change variable. The two-period lead, for example, takes on a value of 1 if the individual is 2 election cycles away from having their polling place changed and zero otherwise. As the plot shows, those whose polling places change become less likely to vote in general elections. This effect does not seem to manifest before the polling place change, helping to alleviate concerns about a violation of the parallel trends assumption.

\section{A.4 Assembling the North Carolina Analysis Dataset}

I use data from three different sources for the analysis. First, I collected lists of polling place addresses and their corresponding precincts from North Carolina County Boards of Elections for every primary and general election in North Carolina from 2006-2016. To date, I have full polling place lists from 35 counties. Although this does not introduce any obvious bias into the analysis, it would be important to know how specific the estimates are to the types of counties for which I could acquire data on polling place locations. Table A.6 shows a comparison of my sample to the full set of North Carolina counties. The counties with 
polling place data are a bit more populous, partly driven by the inclusion of North Carolina's two biggest counties, Mecklenburg and Wake. On every other dimension my sample looks extremely similar to other North Carolina counties, so I suspect the result might generalize to other North Carolina counties.

Table A.6 - County Covariates (2010 Census)

\begin{tabular}{lcc}
\hline \hline Covariate & Mean (All Counties) & Mean (Counties with Data) \\
\hline Total Population & 95355 & 124928 \\
Percent Age 20 to 29 & 0.135 & 0.140 \\
Percent Age 30 to 44 & 0.204 & 0.213 \\
Percent Age 45 to 59 & 0.207 & 0.204 \\
Percent Age 60 to 74 & 0.130 & 0.120 \\
Percent Age 75 and Up & 0.056 & 0.052 \\
Percent Female & 0.513 & 0.513 \\
Percent White & 0.685 & 0.684 \\
Percent Black & 0.215 & 0.213 \\
Percent Hispanic & 0.084 & 0.090 \\
Percent Asian & 0.022 & 0.028 \\
\# Counties & 100 & 35 \\
\hline \hline
\end{tabular}

Second, I use voter file information provided by the North Carolina State Board of Elections. This includes a current voter file as well as various voter file snapshots over the course of the study period. I use these voter files, which have each voter's assigned precinct, to merge them to their assigned polling place location in each election. ${ }^{30}$ In order to avoid the possibility of voters changing addresses and selecting into the polling place change treatment, I limit the analysis only to registrants whose address did not change from the previous election period. These voter files also have useful individual-level information like voter registration address, turnout history, party registration, age, and race. Third, I use homeownership information from CoreLogic, a company that collects housing information from public records, to collect homeownership as an additional covariate.

The process for creating the final dataset is as follows. First, I merged North Carolina registrants to their voting history from the 2008 primary to the 2016 general election. The vote history file contains entries for each ballot cast in an election along with vote method,

\footnotetext{
${ }^{30}$ While the ideal data would include voter file snapshots for each primary and general election in order to observe a voter's assigned precinct on Election Day, I only have snapshots for the following dates: October 20, 2006; November 4, 2008; January 1, 2010; January 1, 2011; May 8, 2012; November 6, 2012; May 6, 2014; November 4, 2014; March 15, 2016; and November 8, 2016. To merge voter precincts to their polling place addresses for each election, I use the precinct from the polling place snapshot closest to the date of the election.
} 
so any registrant-election observation that did not match to a vote history is coded as not having voted.

Second, I assembled a polling place list for every primary and general election from 2006-2016 using information provided by North Carolina County Boards of Elections. These polling place lists include the address of the polling place as well as each polling place's corresponding precinct. I merged the voter file to the polling place information based by precinct and year, creating a file where each registrant-election year has their vote history, registration address, assigned polling place address, and the demographic characteristics available in the voter file. I then generate the polling place change variable, coded simply as a 1 if the registrant's polling place for the previous election cycle is not the same as that registrant's polling place in the current election cycle.

Third, I create a distance metric for every voter's registration address to their assigned polling place. To do this, I use GIS geocoding software to generate the latitude and longitude of both a voter's registered address and the address of their polling place in each year. I calculate each voter's Euclidean (straight-line) distance to their polling place.

Next, I merge in homeowner information from property records data. The property records come from CoreLogic, and private data vendor that collects publicly available tax and deed records from each county in the United States. Each row in the CoreLogic data is a parcel. I have property information for each year from 2006 through 2016. From each of these CoreLogic history files, I keep all parcels defined as single-family residential, condominium, or duplex. Each row contains information on the owner's full name, parcel address and sale date. I merge each these CoreLogic files into the dataset on last name, first name, and zip code, and I construct an indicator for whether or not a registrant was a homeowner at any point between election periods. Finally, I merge in zip-code level data on the percent of the zip-code defined as urban by the US Census. The final dataset, therefore, has registrantelections as the unit of observation, and it contains individual-level information on turnout, polling place change, polling place distance, age, race, homeownership, as well as zip-code level information on percent urban.

For precinct and zip code-level analyses, I simply collapse the individual-level dataset before merging in relevant information. In the case of the precinct-level vote share analysis, I collapse the dataset by precinct-year and merge in the Democratic two-party vote share for each precinct and election year using election returns from the North Carolina State Board of Elections. For the zip code-level analysis, I collapse the dataset by zip code-year - taking the mean of the polling place change indicator variable - and merge in the Federal Election Commission disbursements data for the North Carolina Democratic and Republican parties for each zip code and election year. 


\section{A.5 Other Tables and Figures}

Table A.7 - Descriptive Statistics, General Election Observations, Individual Level, North Carolina, 2008-2016.

\begin{tabular}{lccccc}
\hline \hline & $\begin{array}{c}\text { Mean } \\
(1)\end{array}$ & $\begin{array}{c}\text { Deviation } \\
(2)\end{array}$ & $\begin{array}{c}\text { Min } \\
(3)\end{array}$ & $\begin{array}{c}\text { Max } \\
(4)\end{array}$ & $\begin{array}{c}\mathrm{N} \\
(5)\end{array}$ \\
\hline Democrat & 0.417 & 0.493 & 0 & 1 & $13,315,719$ \\
Republican & 0.319 & 0.466 & 0 & 1 & $13,315,719$ \\
Unaffiliated & 0.263 & 0.441 & 0 & 1 & $13,315,719$ \\
Black & 0.210 & 0.408 & 0 & 1 & $13,315,719$ \\
White & 0.725 & 0.446 & 0 & 1 & $13,315,719$ \\
Other Non-White & 0.043 & 0.204 & 0 & 1 & $13,315,719$ \\
Percent Urban & 0.745 & 0.319 & 0 & 1 & $13,279,854$ \\
Homeowner & 0.294 & 0.456 & 0 & 1 & $13,315,719$ \\
Age & 48.023 & 17.485 & 18 & 99 & $13,203,263$ \\
\hline \hline Note: All covariates are measured at the individual level except \\
percent urban, which is a zip-code level measure.
\end{tabular}




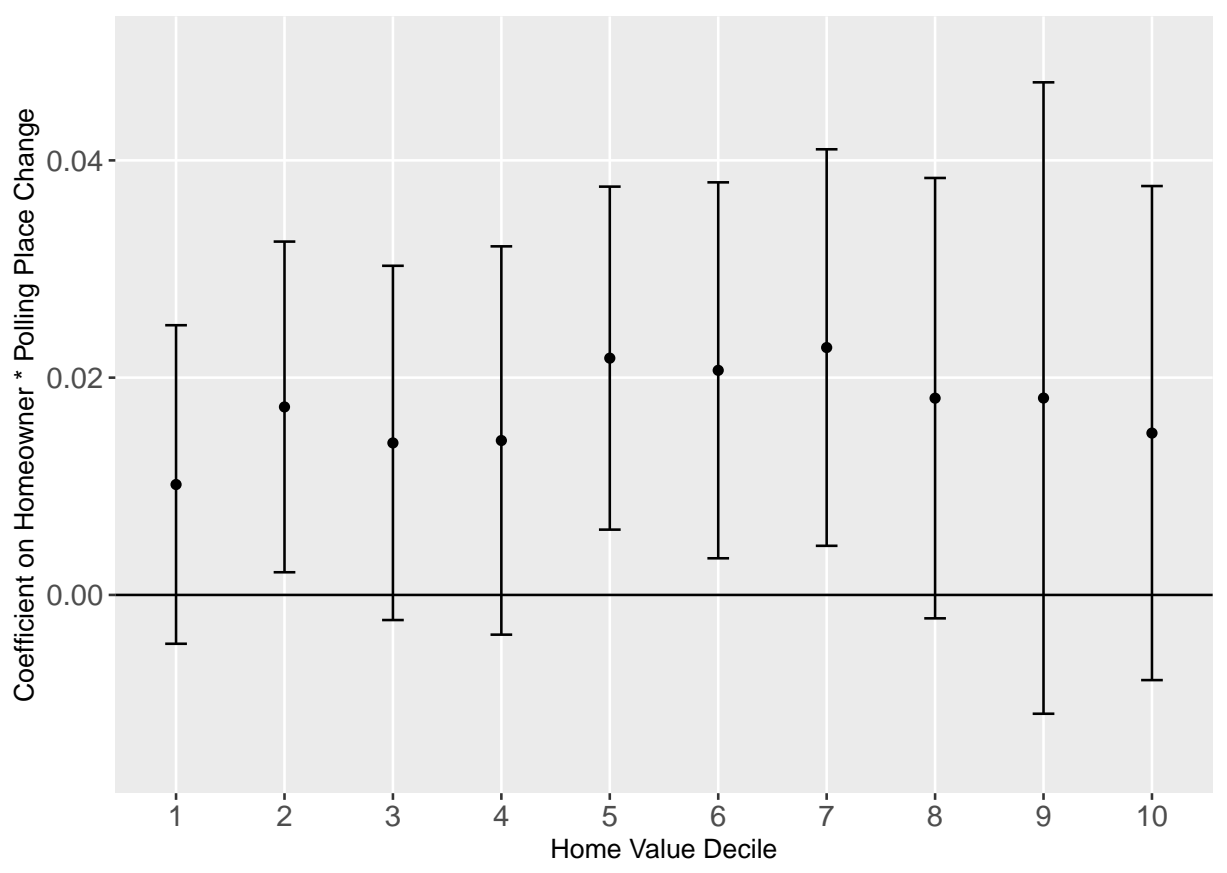

Figure A.4 - Difference in Effects of Polling Place Changes for Homeowners Versus Non-Homeowners, by Home Value

This figure shows coefficient estimates of the interaction term in Column 1 of Table 5 across home value deciles. The $\mathrm{x}$-axis is the decile of home value among homeowners. The dotted line represents the coefficient estimate of the interaction term from the specification in Column 1 of Table 5. Each point represents a coefficient estimate from the specification in Column 1 of Table 5 , but using only those within each home value decile. There appears to be no relationship between home value and the difference in effects of polling place changes for homeowners relative to nonhomeowners. This provides suggestive evidence that homeowners are less sensitive to polling place changes compared to non-homeowners, regardless of wealth. 


\section{Democrat}

\section{Republican}

Black

White

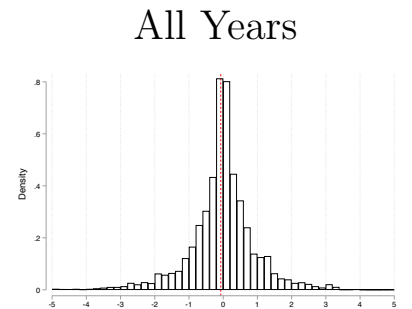

Democratic Boards

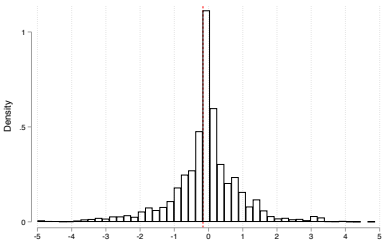

Republican Boards
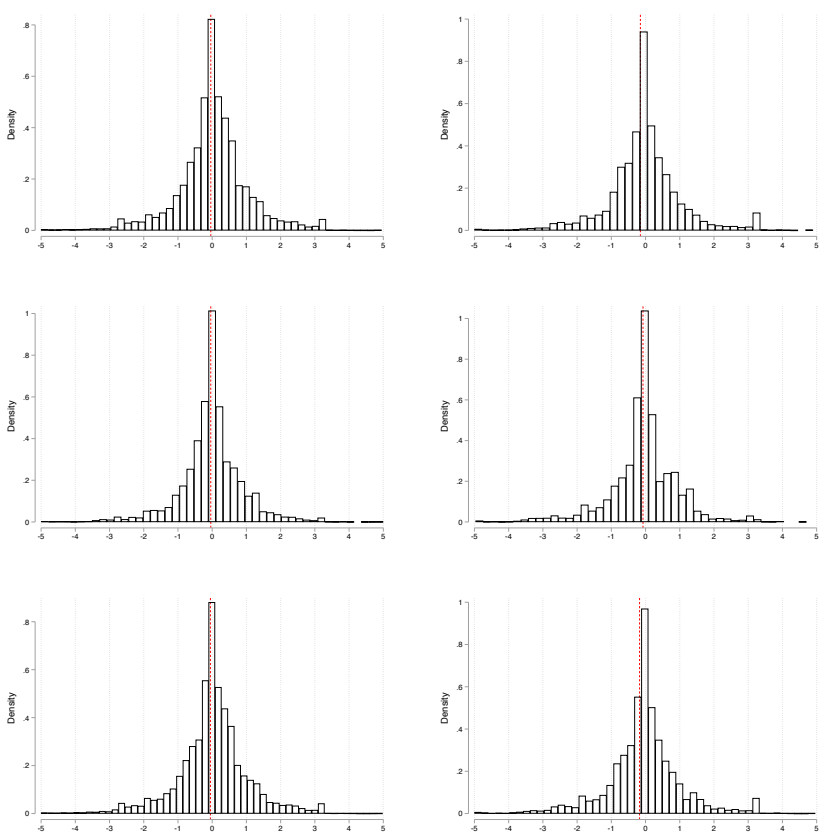
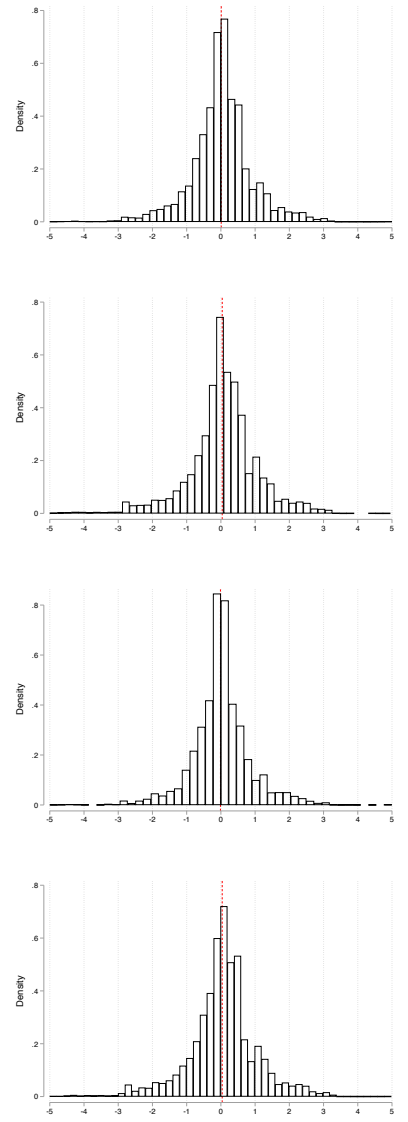

Figure A.5 - Change in Polling Place Distance (Miles)

Each figure shows the distribution of change in general election polling place distance for different subgroups of voters that experience polling place changes. The row indicates the subgroup of voters, and the column indicates the years. The first column includes all years (2008-2016), the second column includes only years where the partisan composition of county boards of elections were Democratic (20082012), and the third column includes only years where the partisan composition of county boards of elections were Republican (2014-2016). 
Table A.8 - Effects of Polling Place Changes on General Election Turnout, Individual Level, 2008-2016.

\begin{tabular}{lcccccc}
\hline \hline \multirow{2}{*}{ Sample } & \multicolumn{2}{c}{ Voted Absentee by Mail } & \multicolumn{3}{c}{ Voted Early in Person } \\
& Full & Primary & General & Full & Primary & General \\
& $(1)$ & $(2)$ & $(3)$ & $(4)$ & $(5)$ & $(6)$ \\
\hline PP Change & 0.000 & 0.003 & 0.002 & -0.002 & 0.008 & 0.006 \\
& $(0.001)$ & $(0.002)$ & $(0.001)$ & $(0.003)$ & $(0.015)$ & $(0.009)$ \\
\hline $\mathrm{N}$ & $13,315,719$ & $2,383,802$ & $1,595,522$ & $13,315,719$ & $2,383,802$ & $1,595,522$ \\
$\#$ Voters & $3,869,787$ & $1,257,927$ & $1,100,761$ & $3,869,787$ & $1,257,927$ & $1,100,761$ \\
Election FEs & Yes & Yes & Yes & Yes & Yes & Yes \\
Voter FEs & Yes & Yes & Yes & Yes & Yes & Yes \\
\hline \hline
\end{tabular}

Note: Robust standard errors clustered by precinct in parentheses. The outcome in Columns 1-3 is a whether an individual voted absentee by mail in the general election, and the outcome in Columns 4-6 is whether an individual voted early in person in the general election. The full sample includes all voters, the primary sample subsets to individuals who voted in the primary election in the present year, and the general sample subsets to individuals who voted in the prior general election but not in the primary in the present year. PP Change is a binary variable indicating whether an individual had her Election Day polling place location changed from the previous general election (or from the primary election for the primary sample).

Table A.9 - Effects of Polling Place Changes on Primary Election Turnout, Individual Level, 2008-2016.

\begin{tabular}{lcccccc}
\hline \hline \multirow{2}{*}{ Sample } & \multicolumn{2}{c}{ Voted } & \multicolumn{2}{c}{ Voted at Polling Place } & \multicolumn{2}{c}{ Voted Convenience } \\
& Full & General & Full & General & Full & General \\
& $(1)$ & $(2)$ & $(3)$ & $(4)$ & $(5)$ & $(6)$ \\
\hline PP Change & 0.002 & -0.014 & -0.001 & -0.016 & 0.003 & 0.003 \\
& $(0.004)$ & $(0.008)$ & $(0.003)$ & $(0.008)$ & $(0.002)$ & $(0.002)$ \\
\hline $\mathrm{N}$ & $12,063,514$ & $2,596,017$ & $12,063,514$ & $2,596,017$ & $12,063,514$ & $2,596,017$ \\
$\#$ Voters & $3,650,894$ & $1,416,549$ & $3,650,894$ & $1,416,549$ & $3,650,894$ & $1,416,549$ \\
Election FEs & Yes & Yes & Yes & Yes & Yes & Yes \\
Voter FEs & Yes & Yes & Yes & Yes & Yes & Yes \\
\hline \hline
\end{tabular}

Note: Robust standard errors clustered by precinct in parentheses. The outcome in Columns 1 and 2 is a whether an individual voted in the primary election, the outcome in Columns 3 and 4 is whether an individual voted at her polling place in the primary election, and the outcome in Columns 5 and 6 is whether an individual voted using convenience methods in the primary election. The full sample includes all voters, and the general sample subsets to individuals who voted at their polling place in the prior general election. PP Change is a binary variable indicating whether an individual had her Election Day polling place location changed from the previous primary election (or from the previous general election for the general sample). 


\section{Table A.10 - Effects of Polling Place Changes on General Elec- tion Turnout by Democrat, Black, and Percent Urban; Individual Level, 2008-2016.}

\begin{tabular}{|c|c|c|c|c|c|c|c|c|c|}
\hline & \multicolumn{3}{|c|}{ Voted } & \multicolumn{3}{|c|}{ Voted at Polling Place } & \multicolumn{3}{|c|}{ Voted Convenience } \\
\hline & (1) & $(2)$ & $(3)$ & (4) & (5) & (6) & (7) & (8) & (9) \\
\hline PP Change & $\begin{array}{l}-0.011 \\
(0.002)\end{array}$ & $\begin{array}{l}-0.011 \\
(0.002)\end{array}$ & $\begin{array}{c}-0.016 \\
(0.005)\end{array}$ & $\begin{array}{c}-0.007 \\
(0.003)\end{array}$ & $\begin{array}{c}-0.009 \\
(0.003)\end{array}$ & $\begin{array}{c}-0.008 \\
(0.006)\end{array}$ & $\begin{array}{c}-0.004 \\
(0.004)\end{array}$ & $\begin{array}{c}-0.001 \\
(0.004)\end{array}$ & $\begin{array}{c}-0.008 \\
(0.007)\end{array}$ \\
\hline Dem & $\begin{array}{l}-0.036 \\
(0.002)\end{array}$ & & & $\begin{array}{c}-0.003 \\
(0.002)\end{array}$ & & & $\begin{array}{l}-0.033 \\
(0.002)\end{array}$ & & \\
\hline PP Change * Dem & $\begin{array}{l}-0.001 \\
(0.002)\end{array}$ & & & $\begin{array}{l}-0.007 \\
(0.004)\end{array}$ & & & $\begin{array}{c}0.006 \\
(0.004)\end{array}$ & & \\
\hline PP Change * Black & & $\begin{array}{l}-0.005 \\
(0.004)\end{array}$ & & & $\begin{array}{c}-0.004 \\
(0.006)\end{array}$ & & & $\begin{array}{c}-0.000 \\
(0.008)\end{array}$ & \\
\hline Pct Urban & & & $\begin{array}{c}-0.057 \\
(0.006)\end{array}$ & & & $\begin{array}{l}-0.027 \\
(0.004)\end{array}$ & & & $\begin{array}{c}-0.029 \\
(0.005)\end{array}$ \\
\hline PP Change $*$ Pct Urban & & & $\begin{array}{c}0.006 \\
(0.006)\end{array}$ & & & $\begin{array}{l}-0.003 \\
(0.009)\end{array}$ & & & $\begin{array}{c}0.010 \\
(0.009)\end{array}$ \\
\hline $\mathrm{N}$ & $13,315,719$ & $13,315,719$ & $13,279,854$ & $13,315,719$ & $13,315,719$ & $13,279,854$ & $13,315,719$ & $13,315,719$ & $13,279,854$ \\
\hline \# Voters & $3,869,787$ & $3,869,787$ & $3,856,005$ & $3,869,787$ & $3,869,787$ & $3,856,005$ & $3,869,787$ & $3,869,787$ & $3,856,005$ \\
\hline Election FEs & Yes & Yes & Yes & Yes & Yes & Yes & Yes & Yes & Yes \\
\hline Voter FEs & Yes & Yes & Yes & Yes & Yes & Yes & Yes & Yes & Yes \\
\hline
\end{tabular}




\section{POLLING PLACE NAME CHANGE}

Figure A.6 - Wake County Polling Place Name Change Insert 